\title{
CATALYTIC FABRIC FILTRATION FOR SIMULTANEOUS NO AND PARTICULATE CONTROL
}

Quarterly Technical Progress Report

October 1 through December 31, 1993

Contract No. DE-AC22-90PC90361

Submitted to:

COR: Ms. Felixa Eskey

U.S. Department of Energy

Pittsburgh Energy Technology Center

626 Cochran Mill Road

PO Box 10940, MS 922-H

Pittsburgh, PA 15236-0940

Submitted by:

Greg F. Weber

Sumitra R. Ness

Grant L. Schelkoph

Energy \& Environmental Research Center

University of North Dakota

PO Box 9018

DISCLAIMER

Grand Forks, ND 58202-9018

This report was prepared as an account of work sponsored by an agency of the United States Government. Neither the United States Government nor any agency thereof, nor any of their employees, makes any warranty, express or implied, or assumes any legal liability or responsibility for the accuracy, completeness, or usefulness of any information, apparatus, product, or process disclosed, or represents that its use would not infringe privately owned rights. Reference herein to any specific commercial product, process, or service by trade name, trademark, manufacturer, or otherwise does not necessarily constitute or imply its endorsement, recommendation, or favoring by the United States Government or any agency thereof. The views and opinions of authors expressed herein do not necessarily state or reflect those of the United States Government or any agency thereof.

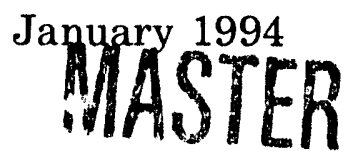




\section{DISCLAIMER}

This report was prepared as an account of work sponsored by an agency of the United States Government. Neither the United States Government nor any agency thereof, nor any of their employees makes any warranty, express or implied, or assumes any legal liability or responsibility for the accuracy, completeness, or usefulness of any information, apparatus, product, or process disclosed or represents that its use would not infringe privately owned rights. Reference herein to any specific commercial product, process, or service by trade name, trademark, manufacturer, or otherwise, does not necessarily constitute or imply its endorsement, recommendation, or favoring by the United States Government or any agency thereof. The views and opinions of authors expressed herein do not necessarily state or reflect those of the United States Government or any agency thereof. 
TABLE OF CONTENTS

$\underline{\text { Page }}$

LIST OF FIGURES $\ldots \ldots \ldots \ldots \ldots \ldots \ldots \ldots \ldots \ldots \ldots \ldots \ldots \ldots$ ii

LIST OF TABLES $\ldots \ldots \ldots \ldots \ldots \ldots \ldots \ldots \ldots \ldots \ldots \ldots \ldots \ldots \ldots$

1.0 INTRODUCTION $\ldots \ldots \ldots \ldots \ldots \ldots \ldots \ldots \ldots \ldots \ldots \ldots \ldots \ldots \ldots$

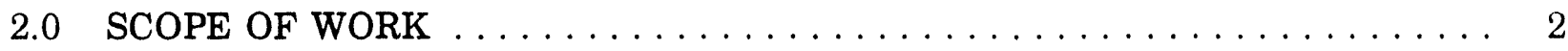

3.0 GOALS AND OBJECTIVES $\ldots \ldots \ldots \ldots \ldots \ldots \ldots \ldots \ldots \ldots$

4.0 ACCOMPLISHMENTS $\ldots \ldots \ldots \ldots \ldots \ldots \ldots \ldots \ldots \ldots \ldots \ldots \ldots$

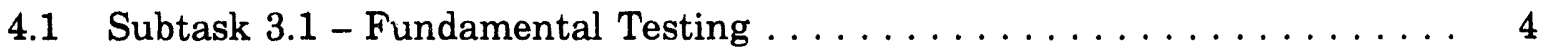

4.2 Subtask 3.2 - Process Testing/Reverse-Gas System . . . . . . . . . . . . 11

4.3 Subtask 3.3 - Process Testing/Pulse-Jet System . . . . . . . . . . . . . . . . 13

4.4 Subtask 3.4 - Fabric Durability Testing/Pulse-Jet System . . . . . . . . . . 13

4.5 Task 4 - Conceptual Design and Economic Evaluation . . . . . . . . . 17

5.0 KEY PERSONNEL STAFFING REPORT $\ldots \ldots \ldots \ldots \ldots \ldots \ldots \ldots$

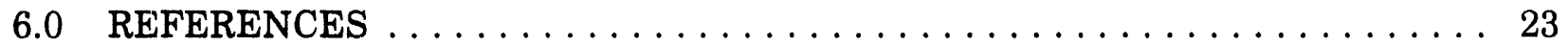




\section{LIST OF FIGURES}

Figure

$\underline{\text { Page }}$

1 Schematic of bench-scale reactor system $\ldots \ldots \ldots \ldots \ldots \ldots$

$2 \mathrm{NO}_{\mathrm{x}}$ removal and ammonia slip versus ammonia-to- $\mathrm{NO}_{\mathrm{x}}$ molar ratio for bench-scale fabric screening tests $\ldots \ldots \ldots \ldots \ldots \ldots \ldots \ldots$

$3 \quad \mathrm{NO}_{\mathrm{x}}$ removal and ammonia slip versus ammonia-to- $\mathrm{NO}_{\mathrm{x}}$ molar ratio for coaland oil-fired test periods using the pilot-scale pulse-jet baghouse . . . . . . . 13

4 Steam plant baghouse mean temperature versus run time $\ldots \ldots \ldots \ldots 17$

5 Steam plant baghouse face velocity versus run time $\ldots \ldots \ldots \ldots \ldots$

6 Steam plant baghouse differential pressure versus run time $\ldots \ldots \ldots \ldots$

7 A summary of multicyclone data for ash collected in the steam plant

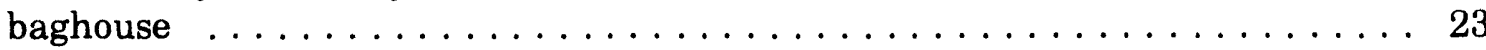

8 Mass emissions and pressure drop as a function of time for the steam plant

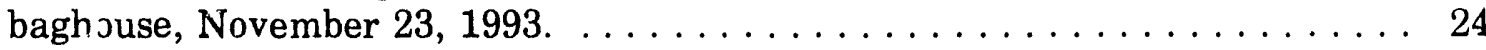

\section{LIST OF TABLES}

Table

$\underline{\text { Page }}$

1 Bench-Scale Catalyst Deactivation Test Results $\ldots \ldots \ldots \ldots \ldots$

2 Coal Ash Analysis for Catalyst Deactivation Tests . . . . . . . . . . 8

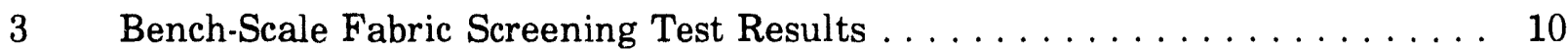

4 XRF Analysis of Steam Plant Baghouse Hopper Ash, October and November $1993 \ldots \ldots \ldots \ldots \ldots$. . . . . . . . . . . . . . . . . . . . 14

$5 \quad$ Steam Plant Particulate Sampling Data . . . . . . . . . . . . . . . 15

6 Steam Plant Multicyclone Data $\ldots \ldots \ldots \ldots \ldots \ldots$

7 Planned Versus Actual Work Hours for Key Project Personnel Through

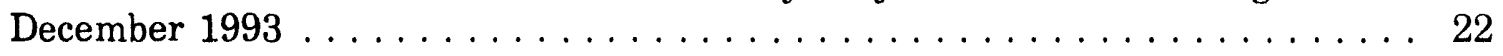




\section{CATALYTIC FABRIC FILTRATION FOR SIMULTANEOUS NO AND PARTICULATE CONTROL}

\subsection{INTRODUCTION}

The University of North Dakota Energy \& Environmental Research Center (EERC), Owens-Corning Fiberglas Corporation (OCF), and Raytheon Engineers \& Constructors (RE\&C) are conducting research to develop a catalytic fabric filter (CFF) for simultaneous $\mathrm{NO}_{\mathrm{x}}$ and particulate control. Funding for the project is being provided by the U.S. Department of Energy/Pittsburgh Energy Technology Center (DOE/PETC), Consolidated Edison Company of New York, Inc. (Con Edison), and the Empire State Electric Energy Research Corporation (ESEERCO). OCF is providing catalyst-coated bags, fabric samples, and technical support as a cost share.

The DOE/PETC funding was secured as a result of a competitive award from the DOE/PETC Advanced $\mathrm{NO}_{\mathrm{x}}$ Control program. The objective of this program is to develop advanced concepts for the removal of $\mathrm{NO}_{x}$ from flue gas emitted by coal-fired utility boilers or for the control of $\mathrm{NO}_{\mathrm{x}}$ formation by advanced combustion modification techniques. Funded projects are required to focus on the development of technology that significantly advances the state of the art, using a process or a combination of processes capable of reducing $\mathrm{NO}_{\mathrm{x}}$ emissions to $60 \mathrm{ppm}$ or less. The concept must have successfully undergone sufficient laboratory-scale development to justify scaleup for further evaluation at the pilot scale (not to exceed $5 \mathrm{MWe}$ in size). Other requirements include production of a nonhazardous waste or a salable by-product. The concept should have application to both new and retrofit coal-fired systems and show the potential for a $50 \%$ cost savings when compared to a commercial selective catalytic reduction (SCR) process capable of meeting the 60-ppm $\mathrm{NO}_{\mathrm{x}}$ emission limit.

The EERC approach to meeting the program objective involves the development of a CFF for simultaneous $\mathrm{NO}_{\mathbf{x}}$ and particulate control. The idea of applying either a permanent or throwaway catalyst to a high-temperature fabric filter for $\mathrm{NO}_{\mathrm{x}}$ control is not new (1-4). However, advances at OCF have shown that a high-activity catalyst can be applied to a high-temperature woven glass cloth, resulting in a fabric filter material that can operate at temperatures higher than commercially available, coated glass fabric. The $\mathrm{NO}_{\mathrm{x}}$ is removed by catalytic reduction with ammonia to form nitrogen and water. The catalyst employed at this time is vanadium-titanium, but the exact catalyst composition and the unique method of applying the catalyst to high-temperature glass fabric are the property of OCF (5). Other catalyst options are being evaluated by OCF in order to improve catalyst performance and minimize catalyst cost.

Bench-scale experimental results have shown that over $90 \% \mathrm{NO}_{\mathrm{z}}$ removal can be achieved, that the catalyst-coated fabric has promising self-abrasion characteristics, and that the potential exists for substantially reduced cost compared to conventional SCR and fabric filtration technologies $(6,7)$. However, development of the technology required further evaluation of air-to-cloth ratio effects, ammonia slip, $\mathrm{SO}_{2}$ oxidation to $\mathrm{SO}_{3}$, temperature cycling, catalyst-coated fabric preparation, fuel impacts, fabric cleaning (reverse-gas versus pulse-jet), catalyst life (poisoning and resistance to erosion), and filter performance/life (particulate control, differential pressure, and durability). 


\subsection{SCOPE OF WORK}

The specific approach used to address these issues is represented by the following:

Task 1 - Program Definition

Task 2 - Design and Construct Test Unit

Task 3 - Experimental Program and Data Reduction

Task 4 - Conceptual Design and Economic Evaluation

Task 5 - Test Unit Removal

Task 1, Program Definition, required preparation of a Project Management Plan. This document contains a detailed scope of work, project schedule, and project budget; identifies key project personnel; and presents an appropriate quality assurance/quality control (QA/QC) plan for the project. Task 2, Design and Construct Test Unit, was divided into three subtasks. Subtasks 2.1 and 2.2 involved the detailed design of the test facility on which the experimental program was performed, the construction of the test facility, and an operational shakedown of the system prior to initiating the experimental effort. Subtask 2.3 involved OCF preparation of the catalyst-coated fabric filters that were evaluated in the experimental effort.

Task 3, Experimental Program and Data Reduction, has four subtasks. Subtask 3.1, Fundamental Testing, was intended as a support effort to the primary experimental test plan. This effort supplied information needed to understand the process mechanism thoroughly, allow screening of additional fabric samples, address the issue of catalyst poisoning, and generally support the pilot-scale effort. Subtask 3.2, Process Testing/ Reverse-Gas System, was intended to evaluate process performance in a pilot-scale reverse-gas fabric filter, identify and optimize important process variables, and provide data for a conceptual design. Subtask 3.3, Process Testing/Pulse-Jet System, evaluated process performance in a pilot-scale pulse-jet fabric filter. Subtask 3.4, Fabric Durability Testing/Pulse-Jet System, evaluated catalyst-coated fabric durability and performance for more than 5000 hours in a slipstream pulse-jet baghouse.

Based on the results of Task 3, a technical and economic assessment of the CFF concept, Task 4, Conceptual Design and Economic Evaluation, was completed. Task 5, Test Unit Removal, requires the identification of all major test facilities, equipment, instruments, and hardware and their condition, ownership, and proposed disposition.

The EERC is the primary contractor for the project and is responsible for the management and direction of all technical and administrative project activities. The EERC has, specifically, performed all work associated with Task 1, Subtasks 2.1 and 2.2, and Task 3 and will perform Task 5.

OCF performed and/or supervised tll work associated with Subtask 2.3, including manufacturing the " $\mathrm{S}$ "-glass fabric, coating the fabric, and manufacturing the filter bags for the reverse-gas and pulse-jet systems. This effort, as well as technical support, was provided by OCF as a cost share to the project.

RE\&C, as a subcontractor to the EERC, provided technical support for Task 1 and completed work on Task 4. EERC personnel involved in the Task 3 effort, and OCF personnel provided input to RE\&C Task 4 activities. 
The project schedule was based on a project start date of October 1, 1990, and originally assumed a project duration of 36 months. Therefore, the planned project completion date was September 30, 1993. As of the preparation of this document, authorization has been given to extend the project completion date through March 31 , 1994. The six-month extension permitted the continuation of Subtask 3.4 through December 3, 1993, at no additional cost to the project sponsors. As of the preparation of this report, planned experimental activities for Subtasks 3.1, 3.2, and 3.3 have been completed. Operation of the slipstream baghouse at the UND Steam Plant, Subtask 3.4, resumed in late July and was terminated December 3, 1993. Task 4 activities were completed in early November 1993.

\subsection{GOALS AND OBJECTIVES}

The overall objective of this project is the development of a catalyst-coated fabric filter for simultaneous $\mathrm{NO}_{\mathrm{z}}$ and particulate control. The catalyst-coated fabric filter must provide high removal efficiency for $\mathrm{NO}_{\mathrm{x}}$ and particulate matter. An acceptable bag and catalyst life must be demonstrated, and process economics must show a significant cost savings when compared to a commercial SCR process and conventional particulate control. Specific goals include the following:

- Reduce $\mathrm{NO}_{\mathrm{x}}$ emissions to $60 \mathrm{ppm}$ or less

- Demonstrate particulate removal efficiency of $>99.5 \%$

- Demonstrate a bag/catalyst life of $>1$ year

- Control ammonia slip to $<25 \mathrm{ppm}$

- Show that CFF can achieve a 50\% cost savings over conventional fabric filtration and SCR control technology

- Determine compatibility with $\mathrm{SO}_{2}$ removal systems

- Show that the concept results in a nonhazardous waste product

Specific project activities to be completed during the past quarter (October through December 1993) were to include the following:

- Complete Subtask 3.1 - Fundamental Testing

- Continue Subtask 3.2 - Process Testing/Reverse-Gas System

- Continue Subtask 3.4 - Fabric Durability Testing/Pulse-Jet System

- Complete Task 4 - Conceptual Design and Economic Evaluation 


\subsection{ACCOMPLISHMENTS}

\subsection{Subtask 3.1 - Fundamental Testing}

The planned bench-scale catalyst deactivation experiments were completed this past quarter. An experimental approach representing a worst-case scenario, where the catalyst-coated fabric filters are wetted as a result of an upset condition, was used. During such an upset condition, water may leach various components from the ash layer onto the fabric, creating an alkali-, acid-, or sulfur-rich solution. Depending on the nature of the upset condition, the wetted fabric would either dry quickly because of CFF operating temperatures or remain wetted for an extended period in the event of a forced 'system shutdown.

Fabric samples treated with an acid or base solution were tested after the solution was dried at $240^{\circ} \mathrm{F}$ on the fabric surface and then tested a second time after thorough washing with distilled water. Fabric samples treated with a slurry of the deactivation agent, resulting in a dried dust cake on the surface, were lightly washed with distilled water prior to testing in order to prevent simple fabric blinding from contributing to observed catalyst deactivation. Fabric samples treated with coal ash were also wetted then dried. These bench-scale tests were designed to evaluate the effect of an upset condition on the reactivity of the catalyst-coated fabric with respect to $\mathrm{NO}_{\mathrm{x}}$ reduction and ammonia slip.

Figure 1 illustrates the experimental system used to perform the bench-scale catalyst deactivation experiments. Primary system components include three parallel reactors housed in an electrically heated oven; multiple gas cylinders supplying the

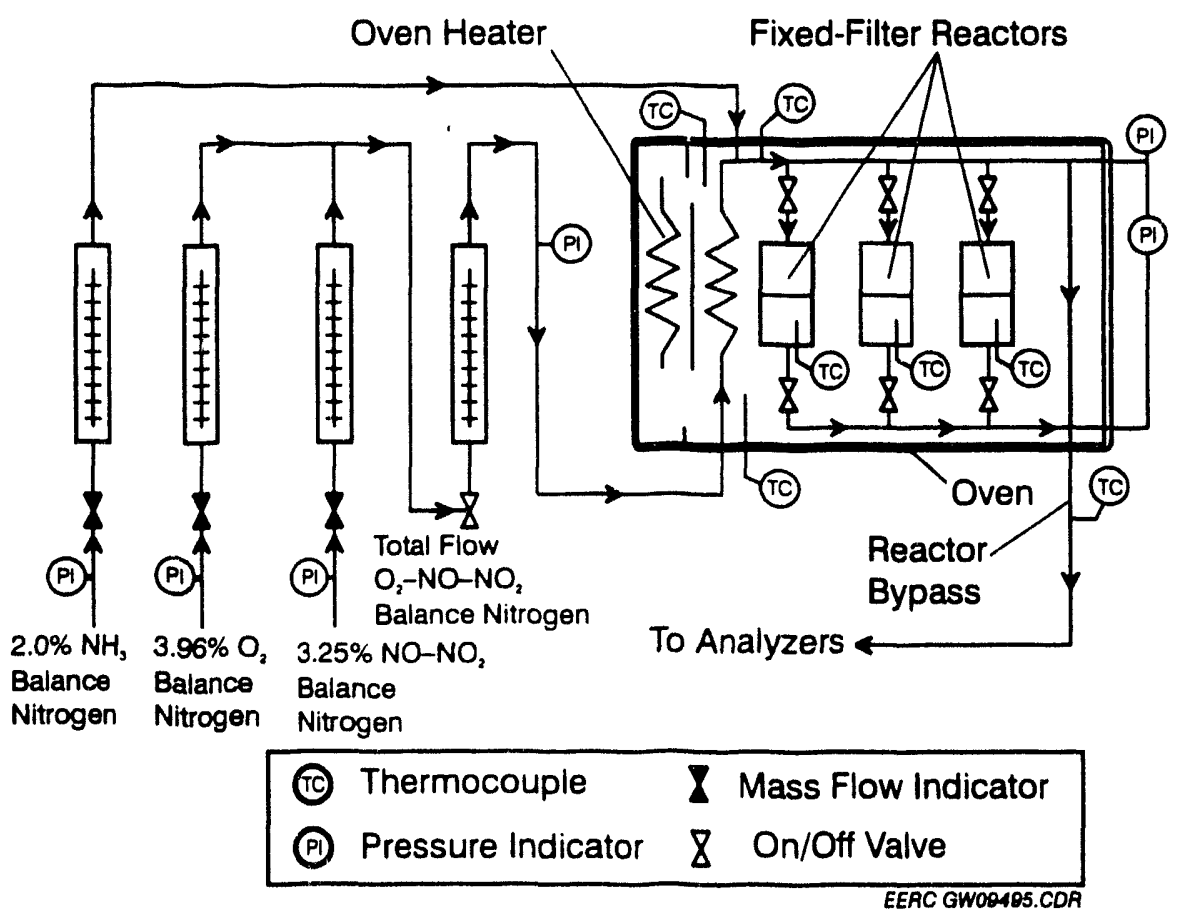

Figure 1. Schematic of bench-scale reactor system. 
necessary components (oxygen, ammonia, and nitric oxide in a nitrogen balance) for the simulated flue gas; and instrument calibration gases, mass flow controllers, flow indicators, and on-line analyzers for measurement of oxygen and nitric oxide concentrations. Ammonia concentrations were measured using colorimetric techniques.

The specific experimental approach involved treating individual catalyst-coated fabric samples with a potential deactivation agent, loading a fabric sample into each of the three reactors, and using a 3- to 4-hour heatup period with no gas flowing through the reactors. Once the reactors had reached the desired operating temperature, simulated flue gas flow was initiated, and desired gas constituent concentrations were verified. Each set of three experiments then required 2 to 3 hours in order to collect and verify the gas data. Specifically, multiple ammonia measurements were necessary during each experiment to ensure reliable data and to document good ammonia closure.

The catalyst-coated fabric type used for the catalyst deactivation experiments was 22-ounce woven S-glass fabric consisting of D-fibers (6.5-micron) prepared using seven coats of an organic-based vanadium/titanium catalyst. This is the same fabric type as that used during the pilot-scale pulse-jet tests. For the catalyst deactivation experiments, reactor temperatures were $650^{\circ}$ to $660^{\circ} \mathrm{F}$, and the filter face velocity was $4 \mathrm{ft} / \mathrm{min}$. The simulated flue gas stream contained 700 to $725 \mathrm{ppm}$ nitric oxide, sufficient ammonia to achieve an ammonia/ $\mathrm{NO}_{x}$ molar ratio of roughly 0.8 , roughly $3.5 \%$ oxygen, and a nitrogen balance.

Table 1 summarizes the results from the catalyst deactivation and fabric screening experiments completed. Each data set in the table represents a single experiment. Ammonia closure was typically $97 \%$ to $103 \%$. As presented in the table, the potential catalyst deactivation agents used included distilled water, tap water, hydrochloric acid $(\mathrm{HCl})$, sulfuric acid $\left(\mathrm{H}_{2} \mathrm{SO}_{4}\right)$, sodium hydroxide $(\mathrm{NaOH})$, calcium oxide $(\mathrm{CaO})$, calcium sulfate $\left(\mathrm{CaSO}_{4}\right)$, potassium sulfate $\left(\mathrm{K}_{2} \mathrm{SO}_{4}\right)$, sodium sulfate $\left(\mathrm{Na}_{2} \mathrm{SO}_{4}\right)$, sodium sulfite $\left(\mathrm{Na}_{2} \mathrm{SO}_{3}\right)$, sodium chloride $(\mathrm{NaCl})$, calcium chloride $\left(\mathrm{CaCl}_{2}\right)$, silicon dioxide $\left(\mathrm{SiO}_{2}\right)$, and three ash samples.

Baseline fabric performance was observed to be $71.5 \% \mathrm{NO}_{\mathrm{x}}$ reduction and $5.6 \%$ ammonia slip at an ammonia $\left(\mathrm{NH}_{3}\right)$ to $\mathrm{NO}_{\mathrm{x}}$ molar ratio of 0.78 . Results from the catalyst deactivation tests show that distilled water $\left(70.4 \% \mathrm{NO}_{\mathrm{x}}\right.$ reduction and $5.6 \%$ ammonia slip) had no effect on catalyst reactivity, and tap water $68 \% \mathrm{NO}_{\mathrm{x}}$ reduction and $6.9 \%$ ammonia slip) may have a minor effect. Both acids, $0.1 \mathrm{M} \mathrm{HCl}$ and $0.1 \mathrm{M} \mathrm{H}_{2} \mathrm{SO}_{4}$, appeared to totally destroy catalyst reactivity initially, but when the fabric samples were thoroughly washed with distilled water and retested, catalyst reactivity was observed io be effectively recovered.

Deactivation experiments with $0.1 \mathrm{M} \mathrm{NaOH}$ resulted in complete loss of catalyst reactivity, $2 \% \mathrm{NO}_{\mathrm{x}}$ reduction, and $>80 \%$ ammonia slip. Washing this fabric sample did not produce any recovery of catalyst reactivity. Even when the $\mathrm{NaOH}$ concentration was decreased to $0.001 \mathrm{M}, \mathrm{NO}_{\mathrm{x}}$ reduction decreased to $58 \%$. Ultimately, all of the sodiumbased catalyst deactivation agents $\left(\mathrm{NaOH}, \mathrm{Na}_{2} \mathrm{SO}_{4}, \mathrm{Na}_{2} \mathrm{SO}_{3}\right.$, and $\left.\mathrm{NaCl}\right)$ tested severely reduced the reactivity of the catalyst-coated fabric. 
TABLE 1

Bench-Scale Catalyst Deactivation Test Results ${ }^{a, b}$

\begin{tabular}{|c|c|c|c|}
\hline $\begin{array}{c}\text { Deactivation } \\
\text { Agent }\end{array}$ & $\begin{array}{c}\mathrm{NH}_{\mathrm{g}} / \mathrm{NO}_{\mathbf{x}} \\
\text { Molar Ratio } \\
\end{array}$ & $\begin{array}{r}\% \mathrm{NO}_{\mathrm{x}} \\
\text { Removal } \\
\end{array}$ & $\begin{array}{c}\mathrm{NH}_{s} \text { Slip, } \\
\text { \% of inlet } \mathrm{NO}_{\mathrm{x}}\end{array}$ \\
\hline DE 992 Fabric, Baseline & 0.78 & 71.5 & 5.6 \\
\hline Distilled $\mathrm{H}_{2} \mathrm{O}$ & 0.78 & 70.4 & 5.6 \\
\hline Tap $\mathrm{H}_{2} \mathrm{O}$ & 0.78 & 68.0 & 6.9 \\
\hline $0.1 \mathrm{M} \mathrm{HCl}$ & 1.16 & 0.0 & 86.0 \\
\hline $0.1 \mathrm{M} \mathrm{HCl}$, washed thoroughly ${ }^{c}$ & 0.85 & 73.4 & 2.76 \\
\hline $0.001 \mathrm{M} \mathrm{HCl}$ & 0.81 & 71.4 & \\
\hline $0.1 \mathrm{M} \mathrm{H}_{2} \mathrm{SO}_{4}$ & 0.85 & 1.0 & 80.7 \\
\hline $0.1 \mathrm{M} \mathrm{H}_{2} \mathrm{SO}_{4}$, washed thoroughly & 0.85 & 71.4 & 2.48 \\
\hline $0.001 \mathrm{M} \mathrm{H}_{2} \mathrm{SO}_{4}$ & 0.81 & 58.4 & $\cdots$ \\
\hline $0.1 \mathrm{M} \mathrm{NaOH}$ & 0.81 & 2.1 & 82.1 \\
\hline $0.1 \mathrm{M} \mathrm{NaOH}$, washed thoroughly & 0.85 & 6.5 & 80.0 \\
\hline $0.001 \mathrm{M} \mathrm{NaOH}$ & 0.81 & 58.4 & $\cdots$ \\
\hline $\mathrm{CaO}$, washed lightly ${ }^{\mathrm{d}}$ & 0.82 & 11.3 & 66.8 \\
\hline $\mathrm{CaSO}_{4}$, washed lightly & 0.86 & 70.4 & 17.8 \\
\hline $\mathrm{K}_{2} \mathrm{SO}_{4}$, washed lightly & 0.86 & 74.1 & 9.2 \\
\hline $\mathrm{Na}_{2} \mathrm{SO}_{4}$, washed lightly & 0.86 & 26.5 & 57.0 \\
\hline $\mathrm{Na}_{2} \mathrm{SO}_{3}$, washed lightly & 0.82 & 2.4 & 74.1 \\
\hline $\mathrm{NaCl}$, washed lightly & 0.81 & 8.7 & 70.2 \\
\hline $\mathrm{CaCl}_{2}$, washed lightly & 0.81 & 14.9 & 68.9 \\
\hline $\mathrm{NaCl}$, washed thoroughly & 0.79 & 24.3 & 54.7 \\
\hline $\mathrm{CaCl}_{2}$, washed thoroughly & 0.79 & 28.3 & 49.9 \\
\hline $\mathrm{SiO}_{2}$, washed thoroughly & 0.80 & 12.1 & 53.5 \\
\hline $\begin{array}{l}\text { Blacksville Bituminous } \\
\text { Ash (low } \mathrm{Ca}, \mathrm{Na} \text { ) }\end{array}$ & 0.82 & 37.6 & 43.8 \\
\hline $\begin{array}{l}\text { Falkirk Lignite } \\
\text { Ash (high } \mathrm{Ca} \text {, low } \mathrm{Na} \text { ) }\end{array}$ & 0.82 & 34.7 & 44.6 \\
\hline $\begin{array}{l}\text { Beulah Lignite } \\
\text { Ash (high } \mathrm{Ca}, \mathrm{Na} \text { ) }\end{array}$ & 0.82 & 3.28 & 80.7 \\
\hline
\end{tabular}


TABLE 1 (continued)

\begin{tabular}{|c|c|c|c|}
\hline $\begin{array}{c}\text { Deactivation } \\
\text { Agent }\end{array}$ & $\begin{array}{c}\mathrm{NH}_{3} / \mathrm{NO}_{\mathrm{x}} \\
\text { Molar Ratio }\end{array}$ & $\begin{array}{c}\% \mathrm{NO}_{\mathrm{x}} \\
\text { Removal }\end{array}$ & $\begin{array}{c}\mathrm{NH}_{3} \text { Slip, } \\
\% \text { of inlet } \mathrm{NO}_{\mathrm{x}}\end{array}$ \\
\hline \multicolumn{4}{|l|}{ 500-hr Fabric } \\
\hline Baseline & 0.80 & 75.8 & 3.72 \\
\hline Wetted $\left(\operatorname{tap} \mathrm{H}_{2} \mathrm{O}\right)$ & 0.80 & 73.8 & 4.16 \\
\hline Acid $\left(0.1 \mathrm{M} \mathrm{H}_{2} \mathrm{SO}_{4}\right)$ & 0.80 & $\cong 20$ & unmeasurable \\
\hline Acid washed & 0.80 & $<3$ & 97.3 \\
\hline \multicolumn{4}{|l|}{ 1640-hr Fabric } \\
\hline Baseline & 0.82 & 72.8 & 3.5 \\
\hline Wetted $\left(\operatorname{tap} \mathrm{H}_{2} \mathrm{O}\right)$ & 0.82 & 70.3 & 4.6 \\
\hline $\operatorname{Acid}\left(0.1 \mathrm{M} \mathrm{H}_{2} \mathrm{SO}_{4}\right)$ & 0.82 & $\cong 36$ & unmeasurable \\
\hline Acid washed & 0.80 & $<10$ & 83.3 \\
\hline \multicolumn{4}{|l|}{ 5136-hr Fabric } \\
\hline Baseline & 0.79 & 75.4 & 4.0 \\
\hline Wetted $\left(\operatorname{tap} \mathrm{H}_{2} \mathrm{O}\right)$ & 0.80 & 70.3 & 6.9 \\
\hline Acid $\left(01 \mathrm{M} \mathrm{H}_{2} \mathrm{SO}_{4}\right)$ & 0.80 & $\cong 47$ & unmeasurable \\
\hline Acid washed & 0.80 & 23 & 18.7 \\
\hline
\end{tabular}

" Typical reactor operating conditions for the catalyst deactivation experiments were a temperature of $650^{\circ}-660^{\circ} \mathrm{F}$, a face velocity of $4 \mathrm{ft} / \mathrm{min}$, an inlet $\mathrm{NO}_{\mathrm{x}}$ concentration of $700-725 \mathrm{ppm}$, and an $\mathrm{NH}_{3} / \mathrm{NO}_{x}$ molar ratio of roughly 0.8 .

b Each data set in the table represents a single experiment. Closure on $\mathrm{NH}_{3}$ was typically $97 \%$ to $103 \%$.

c "Thorough washing" refers to removal of deactivation agent to the greatest possible extent with distilled water.

d Fabric was wetted, coated with deactivation agent, and dried. "Light washing" refers to minimal removal of caked deactivation agent with distilled water to allow for gas flow through the fabric without significant pressure drop.

Of the three calcium-based catalyst deactivation agents $\left(\mathrm{CaO}, \mathrm{CaSO}_{4}\right.$, and $\left.\mathrm{CaCl}_{2}\right)$ tested, $\mathrm{CaO}$ and $\mathrm{CaCl}_{2}$ resulted in the most significant decrease in catalyst reactivity, $11 \%$ to $15 \% \mathrm{NO}_{\mathrm{x}}$ reduction and $66.8 \%$ to $68.9 \%$ ammonia slip. The $\mathrm{CaSO}_{4}$ did not decrease $\mathrm{NO}_{\mathrm{x}}$ reduction as significantly as the sodium-based materials or the other calcium-based materials tested, but there was a significant increase in the ammonia slip observed, with that value approaching $18 \%$ of the inlet $\mathrm{NO}_{\mathrm{x}}$ concentration. Potassium sulfate also had an effect on catalyst reactivity, although substantially less significant than that of the other alkali species. In this case, ammonia slip increased to over $9 \%$ of the inlet $\mathrm{NO}_{\mathrm{x}}$ concentration, as opposed to the $5 \%$ to $6 \%$ observed for the baseline fabric.

The three ash sariples used in the series of experiments represent a bituminous coal and two lignites. Table 2 summarizes the chemical composition for each ash type. The bituminous coal ash contained very little alkali, one lignite ash contained a high level of calcium, and the other lignite ash contained high levels of both calcium and sodium. 
Results from these three experiments are consistent with those observed for the pure chemical deactivation agents tested. Catalyst reactivity was dramatically decreased for all three fabric samples, with the high-sodium ash demonstrating the greatest effect$3.28 \% \mathrm{NO}_{\mathrm{x}}$ reduction and $80.7 \%$ ammonia slip. The two low-sodium ash samples decreased $\mathrm{NO}_{\mathrm{x}}$ reduction to roughly $35 \%$ and increased ammonia slip to $44 \%$.

Two general conclusions can be drawn from these data. First, condensation of an acid on the surface of the clean catalyst-coated fabric interferes with the reactivity of the catalyst. However, catalyst reactivity can be recovered by simply washing the acid from the surface of the catalyst/fabric. Second, exposing the catalyst-coated fabric to a basic or alkali solution will result in varying degrees of catalyst deactivation. A strong base, such as $\mathrm{NaOH}$, will destroy catalyst reactivity. Alkaline solutions in general appear to have a more severe negative effect than acidic solutions on the catalyst reactivity of clean fabric. Solutions containing sodium ions reduce catalyst reactivity more dramatically than calcium ions and calcium ions more dramatically than potassium ions. The degree of catalyst deactivation also varies, depending on the negative ion associated with the sodium or calcium.

Sodium chloride and calcium chloride opposed this trend of stronger alkali causing greater deactivation, with the $\mathrm{NaCl}$ decreasing $\mathrm{NO}_{\mathrm{x}}$ reduction to $14.9 \%$ and $\mathrm{CaCl}_{2}$ decreasing $\mathrm{NO}_{\mathrm{x}}$ reduction to 8.7 percent. Chlorine has been reported to have a promoting effect in $\mathrm{V}_{2} \mathrm{O}_{5} / \mathrm{TiO}_{2}$ catalysts (8). During fabric preparation, all of these slurried compounds formed a solid crystalline layer on the surface of the fabric during the drying step. This solid material was partially removed prior to testing by careful washing with distilled water. Care was taken not to bend the stiffened fabric. The fabrics treated with $\mathrm{NaCl}$ and $\mathrm{CaCl}_{2}$ were retested after a vigorous, thorough washing with distilled water.

TABLE 2

Coal Ash Analysis for Catalyst Deactivation Tests

\begin{tabular}{cccc}
\hline & $\begin{array}{c}\text { Blacksville } \\
\text { Bituminous Coal }\end{array}$ & Beulah Lignite & Falkirk Lignite \\
\hline Oxides, wt\% of ash & & & \\
$\mathrm{SiO}_{2}$ & 46.87 & 25.5 & 42.2 \\
$\mathrm{Al}_{2} \mathrm{O}_{3}$ & 22.58 & 12.3 & 12.1 \\
$\mathrm{Fe}_{2} \mathrm{O}_{3}$ & 18.92 & 11.2 & 12.6 \\
$\mathrm{TiO}_{2}$ & 0.88 & 1.1 & 0.9 \\
$\mathrm{P}_{2} \mathrm{O}_{5}$ & 0.32 & 0.5 & 0.0 \\
$\mathrm{CaO}$ & 5.40 & 18.1 & 20.8 \\
$\mathrm{MgO}$ & 1.01 & 4.3 & 7.0 \\
$\mathrm{Na}_{2} \mathrm{O}$ & 0.77 & 13.07 & 0.6 \\
$\mathrm{~K}_{2} \mathrm{O}$ & 1.44 & 0.6 & 1.5 \\
$\mathrm{SO}_{3}$ & 1.81 & 12.9 & 1.8 \\
\hline
\end{tabular}


The respective $\mathrm{NO}_{\mathrm{x}}$ reduction rates rose to $24.3 \%$ and $28.3 \%$, with ammonia slips around $50 \%$ of inlet $\mathrm{NO}_{\mathbf{x}}$ concentration. One other solid deactivation agent, $\mathrm{SiO}_{2}$, was tested after both light and thorough washing with corresponding $\mathrm{NO}_{\mathrm{x}}$ removal rates of $6.7 \%$ and 12.1\%. During this test, the ammonia closure was poor, possibly from a chemical reaction with the $\mathrm{SiO}_{2}$.

Additional tests to delineate the effects of chlorine as it exists in tap water were not completed after discussing the water purification process steps which contain chlorine with the Grand Forks water department. The residual chlorine in the tap water is not in the form of chlorinated salts or metals; rather, it is in the form of chloramine, $\mathrm{NH}_{2} \mathrm{Cl}$ at 2-2.5 ppm concentration. Chloramine is formed when ammonia is added to the water after it has been contacted with chlorine. This process is used to avoid formation of trihalomethanes. The city water used to deactivate the samples is moderately hard, containing 140-160 mg/L of calcium carbonates, bicarbonates, and sulfates. Since we have shown that $\mathrm{CaSO}_{4}$ deactivates the catalyst, it is presumed that the $\mathrm{CaSO}_{4}$ is the contributing factor causing $2 \%$ less $\mathrm{NO}_{\mathrm{x}}$ reduction with a corresponding $1 \%-2 \%$ higher ammonia slip (as percent of inlet $\mathrm{NO}_{\mathrm{z}}$ ) with the tap water than with the distilled watertreated fabrics.

The final set of deactivation tests involved three fabrics: 1) a PTC pulse-jet bag with 500 hours of operation, 2) a University of North Dakota Steam Plant pulse-jet bag with 1640 hours of operation, and 3) a steam plant pulse-jet bag with 5136 hours of operation. The steam plant ash contained a higher concentration of alkali constituents than the ash from the 500-hr test. Two pieces of each fabric were used; the first was a baseline fabric sample, and the second fabric sample was tested twice, once after treatment with $0.1 \mathrm{M}$ $\mathrm{H}_{2} \mathrm{SO}_{4}$ and once after a thorough washing with distilled water. The baseline tests, conducted at a $\mathrm{NH}_{3} / \mathrm{NO}_{x}$ molar ratio of $0.8 \pm 0.025$ and performed similarly to previous baseline tests, demonstrated from $72 \%-75 \% \mathrm{NO}$, reduction, with ammonia slips less than $5 \%$ of inlet $\mathrm{NO}_{\mathrm{x}}$. Also, the data indicate that no deteciakle loss in catalytic activity was seen from 500 to 1640 to 5136 hours of operation. When the samples were wetted with tap water, the $\mathrm{NO}_{\mathrm{x}}$ reduction fell $2 \%-5 \%$, as reported for previous samples. Though previous tests had been run successfully with $0.1 \mathrm{M} \mathrm{H}_{2} \mathrm{SO}_{4}$ on clean fabric, the tests with the acid and dust cake continued to offgas throughout the test, contaminating the reactors and tubing and almost instantaneously plugging the $\mathrm{NO}_{\mathrm{x}}$ analyzer. The initial $\mathrm{NO}_{\mathrm{x}}$ readings taken indicated that maximum $\mathrm{NO}_{\mathrm{x}}$ conversion was $20 \%$ for the 500 -hr fabric, $36 \%$ for the $1640-\mathrm{hr}$ fabric, and $47 \%$ for the $5136-\mathrm{hr}$ fabric. Ammonia slip measurements could not be made because of the reaction between the acid residue in the system and ammonia. After the fabric samples had been thoroughly washed, the $\mathrm{NO}$, reduction was $3 \%$ for the $500-\mathrm{hr},<10 \%$ for the $1640 \mathrm{hr}$, and $23 \%$ for the $5136 \mathrm{hr}$ fabrics. These rates of recovery show the opposite trend to that expected for ashes with increasingly higher alkali content, but the overall conclusion is that $\mathrm{NO}_{\mathrm{x}}$ reduction cannot be adequately recovered after the ash-coated bags have been exposed to an acid dew point, even after thorough washing. In general the results from the bench-scale catalyst deactivation experiments show that exposure of dust-laden fabric to a severe moisture or acid dew point will permanently reduce catalyst reactivity to a level requiring replacement of the catalyst-coated bags.

Five miscellaneous catalyst-coated fabric samples were also screened in the benchscale system. The fabric screening data in Table 3 represent the data set with the best ammonia balance. 
TABLE 3

Bench-Scale Fabric Screening Test Results

\begin{tabular}{lccc}
\hline Fabric No. & $\begin{array}{c}\mathrm{NH}_{3} / \mathrm{NO}_{\mathrm{x}} \\
\text { Molar Ratio }\end{array}$ & $\begin{array}{c}\% \mathrm{NO}_{\mathrm{x}} \\
\text { Removal }\end{array}$ & $\begin{array}{c}\mathrm{NH}_{s} \text { Slip, } \\
\text { of inlet NO }\end{array}$ \\
\hline Fabric 205 & 0.83 & 25.4 & 61.9 \\
Fabric 206 & 0.83 & 76.1 & 5.6 \\
Fabric 207 & 0.80 & 77.8 & 1.7 \\
Fabric 207 & 1.02 & 94.4 & 7.7 \\
Fabric 208 & 0.80 & 80.4 & \\
Fabric 208 & 0.85 & 84.9 & 1.9 \\
Fabric 208 & 0.91 & 91.0 & 2.1 \\
Fabric 208 & 0.95 & 95.0 & 2.8 \\
Fabric 208 & 1.02 & 97.0 & 2.6 \\
Fabric 209 & & & 5.6 \\
Fabric 209 & 1.02 & 81.0 & \\
\hline
\end{tabular}

Fabric 205 performed very poorly in three trials with $25.4 \% \mathrm{NO}_{\mathrm{x}}$ reduction and an ammonia slip of $61.9 \%$ of the inlet $\mathrm{NO}_{\mathrm{x}}$ concentration. Fabric 209 , performed well with $81.0 \% \mathrm{NO}_{\mathrm{x}}$ reduction at a stoichiometric ratio of 0.83 and an ammonia slip of $1.4 \%$ of the inlet $\mathrm{NO}_{\mathrm{x}}$ concentration. At a stoichiometric ratio of 1.02 Fabric 209 showed a $\mathrm{NO}_{\mathrm{x}}$ reduction of $95.4 \%$ and an ammonia slip of $7.6 \%$ inlet $\mathrm{NO}_{\mathrm{x}}$ concentration. Fabric 208 was tested at stoichiometric values from 0.8 to 0.95 with ammonia slips of approximately $2.5 \%$ of inlet $\mathrm{NO}_{\mathrm{x}}$ concentration. At a stoichiometric ratio of 1.02 , Fabric 208 showed less than stoichiometric $\mathrm{NO}_{\mathrm{x}}$ conversion with $97.0 \% \mathrm{NO}_{\mathrm{x}}$ reduction and an ammonia slip of $5.6 \%$ inlet $\mathrm{NO}_{\mathrm{x}}$ concentration. Fabric 206, with the high-viscosity titania source, appeared to be discolored over portions of the sample. The sample was tested twice with two differently colored areas of fabric. The maximum $\mathrm{NO}_{\mathrm{x}}$ reduction was $76.1 \%$ at a stoichiometric ratio of 0.83 . The corresponding ammonia slip was $5.6 \%$ of the inlet $\mathrm{NO}_{\mathrm{x}}$ concentration. Fabric 206 performed better than clean DE-992 fabric previously tested, which had an average of $71 \% \mathrm{NO}_{\mathrm{z}}$ reduction at a stoichiometric ratio of 0.78 and an ammonia slip of about $5.6 \%$ of inlet $\mathrm{NO}_{\mathrm{x}}$ concentration. Fabric 207 also performed better than clean DE-992 fabric with a ammonia slip of $1.7 \%$ and $\mathrm{NO}_{\mathrm{x}}$ reduction of $77.8 \%$ at a stoichiometric ratio of 0.80 .

Based on this preliminary bench-scale data, Fabric 209 appears to be more reactive than the DE992 used for the pilot-scale pulse-jet tests. If this observation can be substantiated with further bench-scale testing, Fabric 209 may be able to reduce the level of ammonia slip observed during pilot-scale pulse-jest tests form $7 \%$ to $<5 \%$ of the inlet $\mathrm{NO}_{\mathrm{x}}$ concentration. Further testing would be required in order to determine potential performance. 


\subsection{Subtask 3.2 - Process Testing/Reverse-Gas System}

Subtask 3.2 activities this past quarter included completion of routine reporting requirements, performance of some limited bench-scale fabric testing, and initiating work on a draft of the final project report

In two previous Quarterly Technical Progress Reports (April through June 1993 and July through September 1993) the EERC reported results from some initial bench-scale experiments using fabric samples from filter bags used during the 100- and 500-hr pilotscale tests, as well as two bags used during the performance and durability test at the UND Steam Plant. The intent was to evaluate these fabric samples in the bench-scale system in order to determine if there were any differences in catalyst-coated fabric reactivity, as well as the effect of exposure to flue gas as a function of time. The experimental approach, described in a previous report, will not be repeated here (9).

Results of the bench-scale fabric tests completed, including some data not previously reported, are summarized in Figure 2. The new data include a third steam plant bag representing over 5000 hours of flue gas exposure. Each set of data points $\left(\mathrm{NO}_{\mathbf{z}}\right.$ reduction and ammonia slip) represents an arithmetic average of three individual experiments, one experiment for each of the three fabric samples (top, middle, and bottom) removed from each bag tested. The results are presented in this manner because variation in the data for a single bag was typically less than $2 \% \mathrm{NO}_{\mathrm{z}}$ reduction and closure on the ammonia was typically $97 \%$ to $103 \%$.

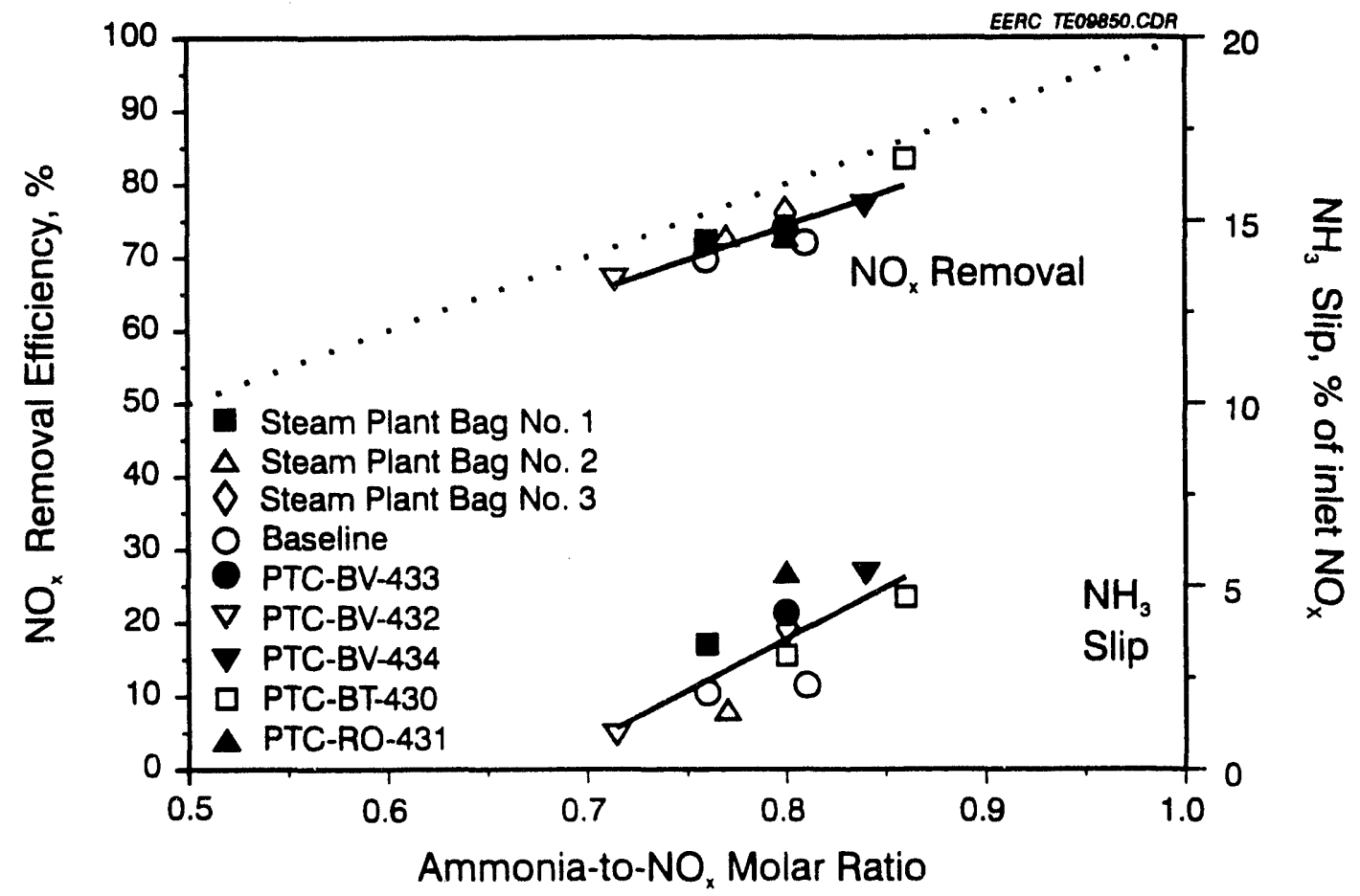

Figure 2. $\mathrm{NO}_{\mathrm{x}}$ removal and ammonia slip versus ammonia-to-NO, molar ratio for bench-scale fabric screening tests. 
The four observations made in the previous reports with respect to this bench-scale data are still valid. First, the fabric samples tested from the three bags removed from the slipstream baghouse at the UND Steam Plant demonstrated $\mathrm{NO}_{\mathrm{x}}$ reduction and ammonia slip levels similar to those observed during the 500-hr test. These data imply that there has not been any significant decrease in catalyst reactivity as a function of the number of hours of flue gas exposure for up to 5136 hours.

Second, all of the fabric samples that had been exposed to a flue gas stream in the pilot-scale pulse-jet baghouse during the $100-\mathrm{hr}$ and $500-\mathrm{hr}$ parametric tests showed equivalent performance in the bench-scale system. Therefore, all of the catalyst-coated bags used during the pilot-scale pulse-jet tests completed appear to have comparable catalyst reactivity after 100 hours of flue gas exposure.

Third, an additional set of bench-scale experiments was completed with fabric samples from bags used during pilot-scale test PTC-BT-430. Initial results indicated that these fabric samples may be slightly more reactive than the other fabric samples tested. Subsequent bench-scale tests have shown fabric samples collected from bags used during test PTC-BT-430 demonstrate reactivity comparable to the other fabric samples tested and the initial data set is within the observed data variability.

Finally, the ammonia slip levels observed in the bench-scale data are similar to those observed in the data set from the 100- and 500-hr pilot-scale experimental periods. The exception is one bench-scale baseline data set represented by a new heat-treated fabric sample. In this case, the ammonia slip was significantly lower in the bench-scale test, $2 \%$ versus $7 \%$ of the inlet $\mathrm{NO}_{\mathrm{z}}$ concentration. A possible explanation for the difference is that the $\mathrm{NH}_{3}$ closure was only $91 \%$ for this particular baseline bench-scale test, indicating that the actual $\mathrm{NH}_{3}$ slip value was probably higher than the value measured.

Figure 3 summarizes all of the coal- and oil-fired pilot-scale pulse-jet data generated. The data show that based on results from the 500 -hr tests, $80 \% \mathrm{NO}_{\mathrm{x}}$ reduction can be achieved at an air-to-cloth ratio of 3 to $3.5 \mathrm{ft} / \mathrm{min}$, an $\mathrm{NH}_{3} / \mathrm{NO}_{\mathrm{x}}$ molar ratio of 0.85 , and roughly $7 \% \mathrm{NH}_{3}$ slip, based on the inlet $\mathrm{NO}_{\mathrm{x}}$ concentration. Data from the 100 -hr pulsejet tests generally indicate better performance (higher $\mathrm{NO}_{\mathrm{x}}$ reduction and lower $\mathrm{NH}_{3}$ slip). However, data from the first 100 hours of each 500-hr test also demonstrated better performance, indicating that fabric reactivity decreased slightly during the first 100 hours of flue gas exposure. Other variability in the data can be attributed to the various fuels fired (Blacksville bituminous coal, Black Thunder subbituminous coal, and fuel oil) and the range of air-to-cloth ratios represented ( 3 to $6 \mathrm{ft} / \mathrm{min}$ ).

The planned pilot-scale experimental activities outlined in the original scope of work have been completed. Remaining activities will include routine reporting and preparation of papers or journal articles deemed appropriate and preparation of a final project report. No additional bench-scale experimental work or fabric analytical characterization is anticipated at this time. 


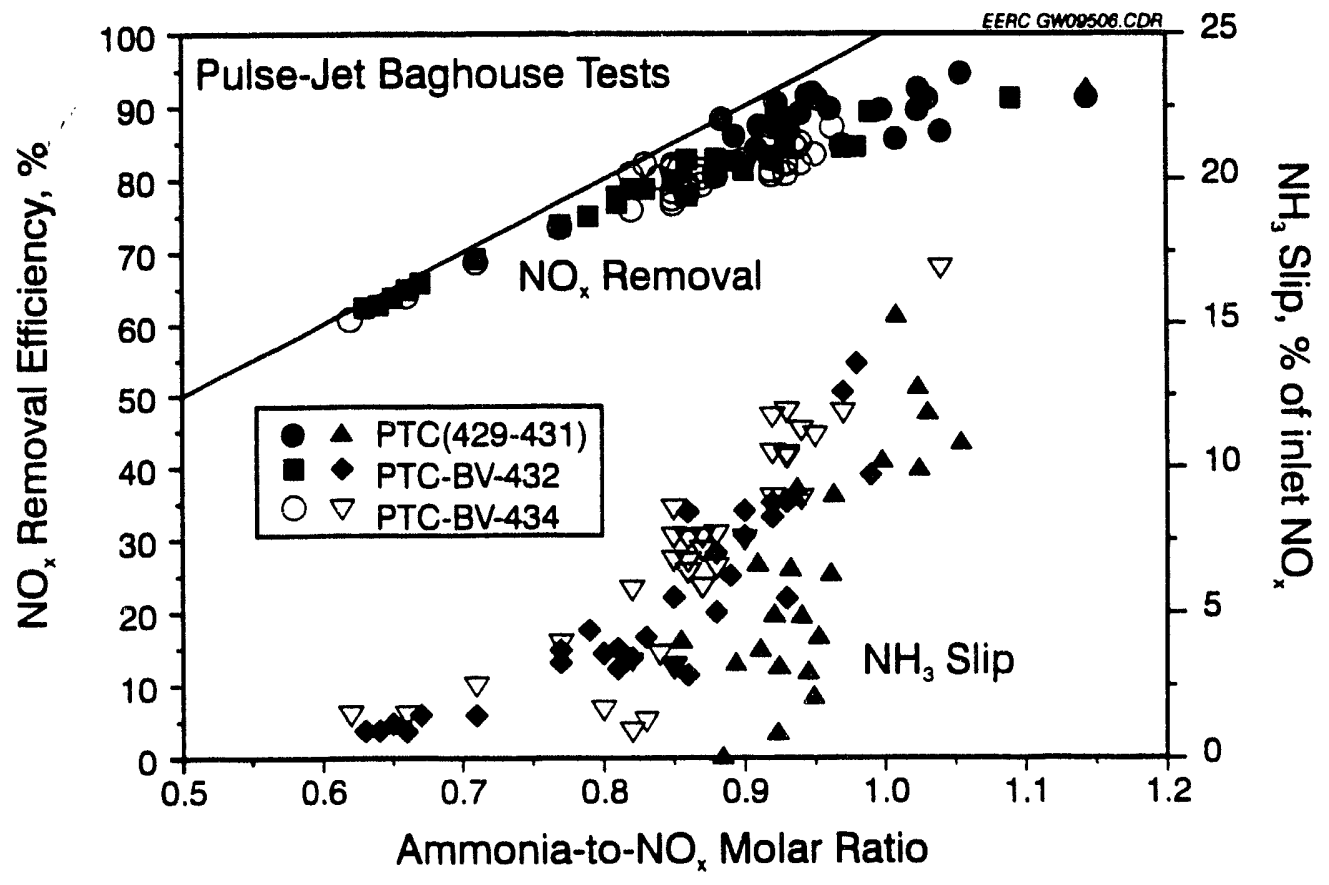

Figure 3. $\mathrm{NO}_{\mathrm{x}}$ removal and ammonia slip versus ammonia-to-NO molar ratio for coaland oil-fired test periods using the pilot-scale pulse-jet baghouse.

\subsection{Subtask 3.3 - Process Testing/Pulse-Jet System}

The three 100-hr pulse-jet tests planned for this subtask were completed in July 1992, and the 500.hr test was completed in August 1992. Results were presented at a project review meeting in October 1992 and summarized in the Quarterly Technical Progress Report for the period July through September 1992. Subtask 3.3 activities have been completed, with the exception of final reporting activities and the preparation of any papers or journal articles deemed appropriate.

\subsection{Subtask 3.4 - Fabric Durability Testing/Pulse-Jet System}

The slipstream baghouse system at the UND Steam Plant operated for most of the months of October and November and for three days in December, accumulating 1175 hours, resulting in 3082 cleaning cycles. The slipstream baghouse did not operate from October 14 through October 27 at the request of the UND Steam Plant personnel because of boiler emissions testing at the steam plant. Also, the slipstream baghouse did not operate from November 25 through November 27 because of a forced shutdown as a result of a power failure at the UND Steam Plant. As of December 3, 1993, the baghouse had accumulated 5136 hours of operating time. During the past quarter, the baghouse operated at an average flue gas temperature of $500^{\circ}$ to $625^{\circ} \mathrm{F}$, an air-to-cloth ratio of 4 to $5 \mathrm{ft} / \mathrm{min}$, and a baghouse differential pressure of nominally 3 to 6 in. W.C.

Figure 4 presents baghouse mean temperature as a function of time for the entire 5136 hours of operation completed through December 3, 1993. Baghouse temperature is 


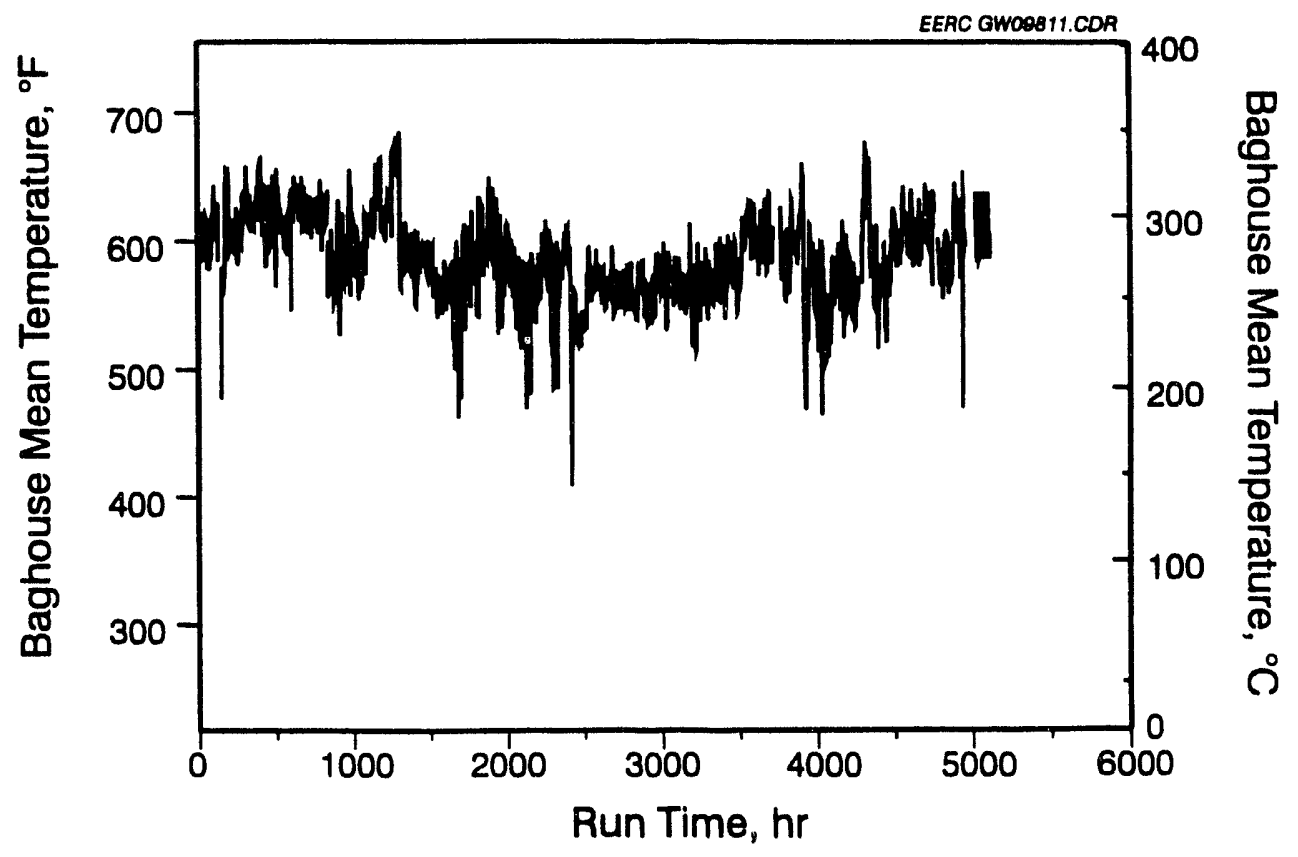

Figure 4. Steam plant baghouse mean temperature versus run time.

presented as an arithmetic mean value based on four thermocouples in the baghouse. The variability in baghouse mean temperature is the result of swings in boiler load. In general, the baghouse mean temperature was relatively low, ranging from $500^{\circ}$ to $625^{\circ} \mathrm{F}$, because of relatively low steam demand in the fall of 1992 , the spring of 1993, and the fall of 1993 and the high excess air levels at which the boiler was operating. If the boiler had operated during the winter months (December, January, and February) and/or at more typical excess air levels, average baghnuse temperature would have been in the $600^{\circ}$ to $700^{\circ} \mathrm{F}$ range. Because of persisting low baghouse mean temperatures, the EERC Project Manager raised the baghouse face velocity from 4 to $4.5 \mathrm{ft} / \mathrm{min}$ to increase average baghouse temperature.

Figure 5 presents baghouse face velocity as a function of time for the entire $\mathbf{5 1 3 6}$ hours of operation. In order to determine face velocity, flue gas flow rates were monitored on a continuous basis using an annubar flow element and verified twice daily by taking pitot measurements. Initially, baghouse face velocity was roughly $3.5 \mathrm{ft} / \mathrm{min}$. After about 500 hours of operation, the face velocity was increased to $4 \mathrm{ft} / \mathrm{min}$ in an attempt to maintain baghouse mean temperature as average boiler load decreased. In November 1992, the face velocity was decreased to $3 \mathrm{ft} / \mathrm{min}$ in order to prevent the baghouse mean temperature from exceeding $700^{\circ} \mathrm{F}$. In April 1993, the face velocity was again increased to $4 \mathrm{ft} / \mathrm{min}$ in order to maintain the baghouse mean temperature above $500^{\circ} \mathrm{F}$. During the past two quarters, face velocity was increased from roughly $4 \mathrm{ft} / \mathrm{min}$ to slightly over $5 \mathrm{ft} / \mathrm{min}$ in order to increase baghouse mean temperature, with little success. 


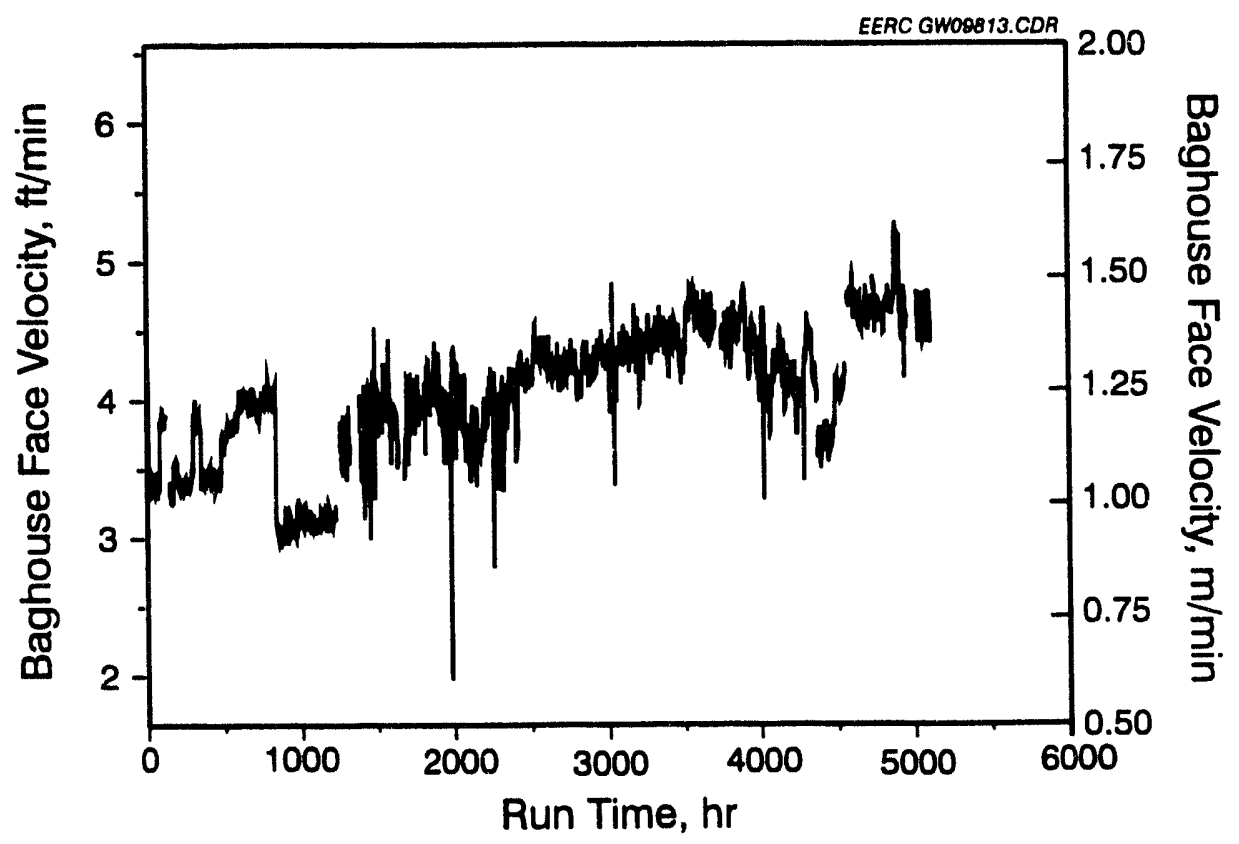

Figure 5. Steam plant baghouse face velocity versus run time.

During the October, November, December operating period, the baghouse was cleaned as a function of differential pressure. The cleaning cycle trigger point was 4 in. W.C., resulting in 3082 cleaning cycles. Cleaning cycles in October totaled 704, and 2378 cleaning cycles were accumulated in November and December.

Figure 6 presents baghouse differential pressure as a function of time for the entire 5136 hours of operation. For most of the 5136 hours of operation completed, the baghouse differential pressure was effectively controlled between 2 and 4 in. W.C. using on-line cleaning. In May 1993, ash loading to the baghouse was increased from $<2 \mathrm{gr} / \mathrm{scf}$ to $>2 \mathrm{gr} / \mathrm{scf}$. This change resulted in a significant increase in the cleaning cycle frequency, and the bags were not cleaning efficiently. In order to prevent frequent cleaning, to establish, a $<20$-min. cleaning cycle frequency, and improve bag cleaning, it was necessary to increase the cleaning cycle trigger point from 4 to $6 \mathrm{in}$. W.C. During the July through September 1993 operating period, the cleaning cycle trigger point was again reduced to $4 \mathrm{in}$. W.C. in order to maintain a 20 - to 30 -minute cleaning frequency. A change in ash properties, probably an increase in particle-size distribution, is believed to be responsible for the change in cleaning frequency. Total cleaning cycles as of December 3,1993 , number 13,820 . The pulse-air reservoir pressure was 43 psig and the pulse duration was 0.1 seconds during the October, November, December operating period.

Ash injection to augment the particulate mass loading from the stoker-fired boiler was continuous during the October, November, December operating period. The injection ash used during this period was a subbituminous ash collected from a pulse-jet baghouse operating on one of the stoker-fired boilers and a bituminous ash collected from a pilotscale pulse-jet baghouse operating in the EERC combustion pilot plant. 


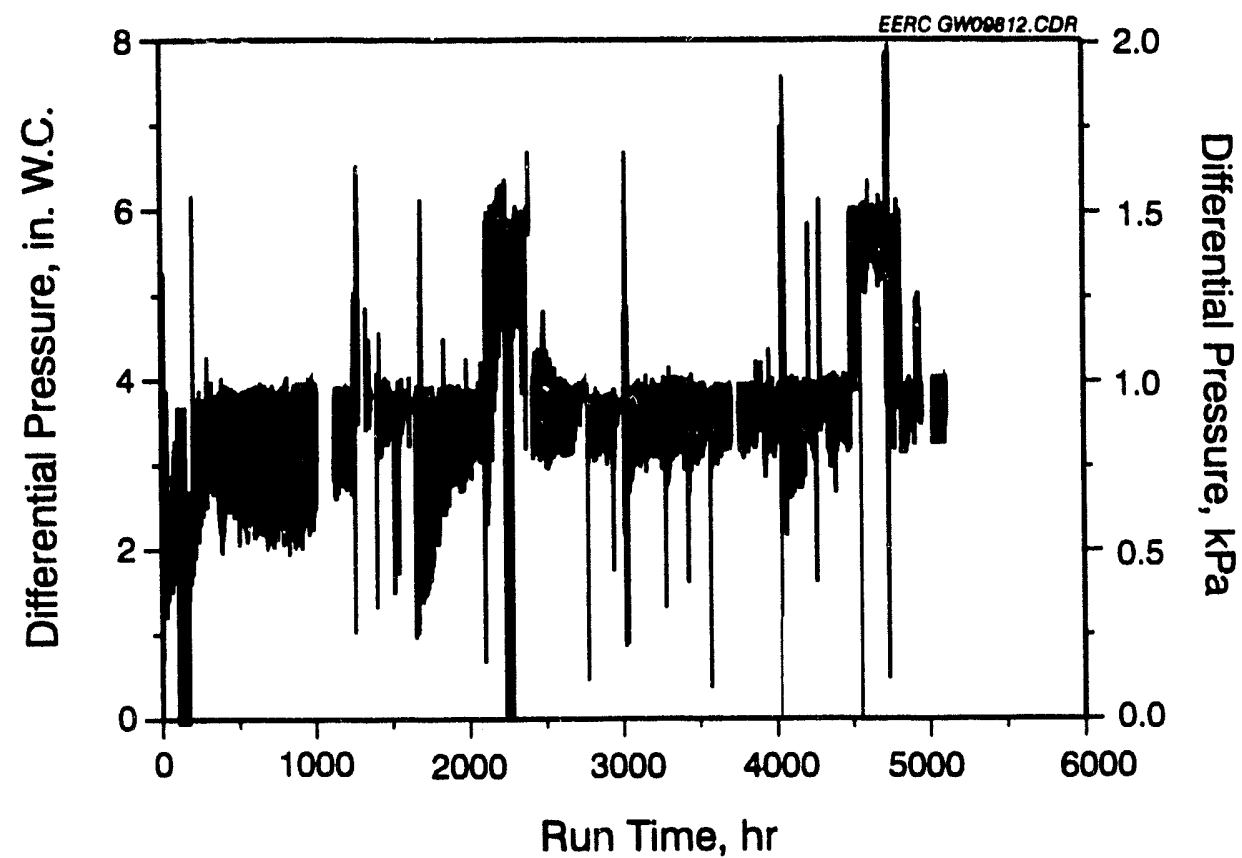

Figure 6. Steam plant baghouse differential pressure versus run time.

Table 4 presents x-ray fluorescence (XRF) analysis results for baghouse hopper ash samples collected in October and November. Primary components included silica, alumina, iron, calcium, and magnesium, all reported as oxides. The loss on ignition (LOI) for these samples was $24.80 \%$ and $9.93 \%$, respectively, resulting from carbon carryover from the stoker-fired boiler. The high carbon concentration in the ash is indicative of extremely poor combustion efficiency in the stoker-fired boiler, probably because of high air velocities through the grate, also resulting in high excess air overall.

Particulate sampling was performed on October 28 and November 23, 1993. Tables 5 and 6 summarize EPA Method 5 and multicyclone sampling data, respectively, for the entire 5136 hours of operation completed. Results for October and November showed particulate collection efficiency ranged from $99.98 \%$ to $99.99 \%$ for four 2 -hr sampling periods for an average inlet mass loading of 2.5 to $5.7 \mathrm{gr} / \mathrm{scf}$. Measured outlet emissions ranged from 0.0003 to $0.0007 \mathrm{gr} / \mathrm{scf}$.

Multicyclone sampling indicated that roughly $80 \%$ of the fly ash entering the baghouse had an aerodynamic diameter of $>8$ microns. Figure 7 summarizes all of the multicyclone data resulting from operation of the pulse-jet baghouse at the UND Steam Plant. The data show that during specific sampling periods, $74 \%$ to $97 \%$ of the fly ash entering the baghouse had an aerodynamic diameter of $>10$ microns.

Figure 8 presents baghouse emissions data generated using the aerodynamic particle sizer (APS) sampling system. Total and respirable mass emissions were low, $<0.1 \mathrm{mg} / \mathrm{m}^{3}$, 
TABLE 4

XRF Analysis of Steam Plant Baghouse Hopper Ash, October and November 1993

\begin{tabular}{lrc}
\hline Oxide & October, wt\% & November, wt\% \\
\hline $\mathrm{SiO}_{2}$ & 41.61 & 45.37 \\
$\mathrm{Al}_{2} \mathrm{O}_{3}$ & 18.87 & 21.57 \\
$\mathrm{Fe}_{2} \mathrm{O}_{3}$ & 9.45 & 15.32 \\
$\mathrm{TiO}_{2}$ & 0.88 & 0.81 \\
$\mathrm{P}_{2} \mathrm{O}_{5}$ & 0.55 & 0.36 \\
$\mathrm{CaO}$ & 15.78 & 8.98 \\
$\mathrm{MgO}$ & 4.10 & 2.09 \\
$\mathrm{Na}_{2} \mathrm{O}$ & 0.75 & 0.67 \\
$\mathrm{~K}_{2} \mathrm{O}$ & 1.18 & 1.19 \\
$\mathrm{SO}_{3}$ & 6.82 & 3.64 \\
Loss on Ignition & 24.80 & 9.93 \\
\hline
\end{tabular}

except during cleaning cycles that resulted in emission spikes in the $1-$ to $3 \cdot \mathrm{mg} / \mathrm{m}^{3}$ range. Emissions based on integrated averages ranged from 0.06 to $0.2 \mathrm{mg} / \mathrm{m}^{3}$.

Sampling was not completed at the outlet of the baghouse to determine sulfur trioxide $\left(\mathrm{SO}_{3}\right)$ concentration. All previous sampling results have shown $\mathrm{SO}_{3}$ concentrations downstream of the baghouse to be less than $1 \mathrm{ppm}$. Therefore, further $\mathrm{SO}_{3}$ sampling was not warranted.

Because of project funding constraints, operation of the slipstream baghouse was terminated on December 3, 1993. One bag was removed from the pulse-jet baghouse at the UND Steam Plant in early December for characterization, and a replacement bag was installed. The baghouse heaters will be kept on until late January 1994 in anticipation of OCF funding continued operation. In the event that OCF elects not to fund continued system operation or has not made a final decision by January 31,1994 , it will be necessary to remove the remaining bags and complete activities necessary to prepare the equipment for long-term inactivity.

\subsection{Task 4 - Conceptual Design and Economic Evaluation}

Raytheon Engineers \& Constructors (RE\&C) has completed work on the conceptual design and economic evaluation. Preliminary results from the new 500-MWe plant case study were presented by RE\&C at the April 29, 1993, project review meeting held at the EERC. Work on the retrofit case study was completed, and a draft of the Task 4 report was made available to EERC and DOE/PETC personnel for review in mid-July. Copies of the draft report, along with EERC review comments, were forwarded to OCF, Con Edison, and ESEERCO personnel in mid-August. After a few minor changes were made in response to reviewer comments, copies of the Task 4 report were distributed to project participants as an attachment to the October 1993 monthly report. 


\section{TABLE 5}

Steam Plant Particulate Sampling Data

\begin{tabular}{|c|c|c|c|c|}
\hline Test Date & $\begin{array}{l}\text { Inlet, } \\
\mathrm{gr} / \mathrm{scf}\end{array}$ & $\begin{array}{c}\text { Outlet, } \\
\text { gr/scf }\end{array}$ & $\% \mathrm{H}_{2} \mathrm{O}$ & \% Efficiency \\
\hline $07-16-92$ & 1.5542 & $\ldots$ & 8.1 & $\ldots$ \\
\hline $07-16-92$ & $\ldots$ & 0.0001 & 6.4 & 99.992 \\
\hline $07-16-92$ & $2.5491^{\mathrm{B}}$ & $\ldots$ & 7.1 & $\ldots$ \\
\hline $08 \cdot 20 \cdot 92$ & 1.7417 & $\ldots$ & 6.3 & $\ldots$ \\
\hline $08-20-92$ & 17.6786 & $\ldots$ & 7.3 & $\ldots$ \\
\hline $08 \cdot 20.92$ & $\ldots$ & 2.5643 & 6.6 & 85.495 \\
\hline 08-20-92 & $14.9548^{\mathrm{a}}$ & $\ldots$ & 6.1 & $\cdots$ \\
\hline $10-29-92$ & 4.0363 & $\ldots$ & 4.6 & $\ldots$ \\
\hline $10-29-92$ & ..- & 0.0008 & 5.2 & 99.986 \\
\hline $10-29-92$ & ... & 0.0010 & 4.2 & 99.974 \\
\hline $10 \cdot 29-92$ & $5.7311^{\mathrm{B}}$ & $\ldots$ & 3.7 & $\cdots$ \\
\hline $11-19-92$ & 3.1900 & $\ldots$ & 6.7 & $\ldots$ \\
\hline $11-19-92$ & ... & 0.0007 & 6.0 & 99.979 \\
\hline $11 \cdot 19 \cdot 92$ & $\ldots$ & 0.0011 & 5.5 & 99.965 \\
\hline $11-19-92$ & $2.6910^{\mathrm{a}}$ & $\ldots$ & 4.8 & --. \\
\hline $04-27-93$ & $1.6709^{\mathrm{a}}$ & $\cdots$ & 5.0 & $\ldots$ \\
\hline $04-27-93$ & $\ldots$ & 0.0001 & 5.4 & 99.994 \\
\hline $04-27-93$ & $\cdots$ & 0.0002 & 5.3 & 99.988 \\
\hline $05 \cdot 14 \cdot 93$ & $2.2604^{\mathrm{a}}$ & $\ldots$ & 6.2 & $\ldots$ \\
\hline $05 \cdot 14-93$ & $\ldots$ & 0.0003 & 5.1 & 99.987 \\
\hline $05-14-93$ & $\cdots$ & 0.0003 & 5.1 & 99.987 \\
\hline 08-04-93 & $2.2821^{\prime \prime}$ & $\ldots$ & 5.4 & $\cdots$ \\
\hline $08-04-93$ & $\ldots$ & 0.0003 & 4.5 & 99.987 \\
\hline $08-04-93$ & $\cdots$ & 0.0004 & 4.2 & 99.983 \\
\hline $09-10-93$ & $1.7974^{\mathrm{u}}$ & $\ldots$ & 3.4 & $\ldots$ \\
\hline $09-10-93$ & 1.9520 & $\cdots$ & 3.9 & $\ldots$ \\
\hline $09-10-93$ & ... & 0.0002 & 5.2 & 99.988 \\
\hline $09 \cdot 10-93$ & $\cdots$ & 0.00102 & 4.5 & 99.988 \\
\hline 09-29-93 & $2.2451^{a}$ & $\cdots$ & 4.5 & $\ldots$ \\
\hline $09-29.93$ & 2.2124 & $\ldots$ & 7.4 & $\ldots$ \\
\hline $09-29-93$ & $\ldots$ & 0.0004 & 5.8 & 99.981 \\
\hline 09.29 .93 & $\ldots$ & 0.0005 & 5.5 & 99.979 \\
\hline $10-28-93$ & $2.5283^{\mathrm{a}}$ & $\ldots$ & 3.4 & $\ldots$ \\
\hline $10-28-93$ & 2.6878 & $\ldots$ & 3.1 & $\ldots$ \\
\hline $10-28-93$ & -.. & 0.0003 & 4.5 & 99.989 \\
\hline $10 \cdot 28-93$ & $\ldots$ & 0.0003 & 4.3 & 99.991 \\
\hline 11.23 .93 & $4.0308^{\mathrm{a}}$ & $\ldots$ & 4.6 & $\cdots$ \\
\hline $11-23-93$ & 5.7246 & $\ldots$ & 5.8 & $\ldots$ \\
\hline 11.23 .93 & -.- & 0.0003 & 5.0 & 99.995 \\
\hline $11.23-93$ & $\cdots$ & 0.0007 & 5.2 & 99.983 \\
\hline
\end{tabular}

"Multicyclone sampling. 
TABLE 6

Steam Plant Multicyclone Data

\begin{tabular}{|c|c|c|c|c|c|c|}
\hline $07-16-92$ & CY1 & CY2 & CY3 & CY4 & CY5 & $\begin{array}{c}\text { Backup } \\
\text { Filter }\end{array}$ \\
\hline $\mathrm{D}_{\mathrm{s0}}, \mu \mathrm{m}$ & 9.24 & 6.07 & 3.27 & 2.23 & 0.93 & $\cdots$ \\
\hline \multicolumn{6}{|l|}{ Mass } & 0.0394 \\
\hline$\%$ Total Mass & 78.21 & 7.30 & 6.29 & 4.35 & 2.97 & 0.88 \\
\hline $\begin{array}{l}\text { Mass Less } \\
\text { Than } \mathrm{D}_{50} \text {, } \\
\text { cumulative \% }\end{array}$ & 21.79 & 14.49 & 8.20 & 3.85 & 0.88 & $\cdots$ \\
\hline \multicolumn{7}{|c|}{ Total Mass Collected $=4.4700 \mathrm{~g}$, Dust Loading $=2.5491 \mathrm{gr} / \mathrm{scf}, \%$ Isokinetic $=99.0$} \\
\hline $08-20-92$ & CY1 & CY2 & CY3 & CY4 & CY5 & $\begin{array}{c}\text { Backup } \\
\text { Filter }\end{array}$ \\
\hline $\mathrm{D}_{50}, \mu \mathrm{m}$ & 8.67 & 5.49 & 2.93 & 2.01 & 0.84 & $\cdots$ \\
\hline $\begin{array}{l}\text { Mass } \\
\text { Collected, g }\end{array}$ & 27.9474 & 0.4742 & 0.1699 & 0.0940 & 0.0730 & 0.0261 \\
\hline$\%$ Total Mass & 97.09 & 1.65 & 0.59 & 0.33 & 0.25 & 0.09 \\
\hline $\begin{array}{l}\text { Mass Less } \\
\text { Than } D_{50}, \\
\text { cumulative \% }\end{array}$ & 2.91 & 1.26 & 0.67 & 0.34 & 0.09 & $\cdots$ \\
\hline \multicolumn{7}{|c|}{ Total Mass Collected $=28.7845 \mathrm{~g}$, Dust Loading $=14.9548 \mathrm{gr} / \mathrm{scf}, \%$ Isokinetic $=100.9$} \\
\hline $10-29.92$ & CY1 & CY2 & CY3 & CY4 & CY5 & $\begin{array}{c}\text { Backup } \\
\text { Filter }\end{array}$ \\
\hline $\mathrm{D}_{50}, \mu \mathrm{m}$ & 10.27 & 7.09 & 3.88 & 2.61 & 1.08 & $\cdots$ \\
\hline $\begin{array}{l}\text { Mass } \\
\text { Collected, g }\end{array}$ & 8.6404 & 0.0919 & 0.0397 & 0.0250 & 0.0278 & 0.0175 \\
\hline$\%$ Total Mass & 97.72 & 1.04 & 0.45 & 0.28 & 0.31 & 0.20 \\
\hline $\begin{array}{l}\text { Mass Less } \\
\text { Than } D_{50}, \\
\text { cumulative \% }\end{array}$ & 2.28 & 1.24 & 0.80 & 0.51 & 0.20 & $\cdots$ \\
\hline Total Mass Co & ted $=8.8$ & g, Dust I & $\operatorname{lng}=5$ & $1 \mathrm{gr} / \mathrm{scf}$, & kineti & 90.6 \\
\hline
\end{tabular}

continued ... 
TABLE 6 (continued)

Steam Plant Multicyclone Data

\begin{tabular}{|c|c|c|c|c|c|c|}
\hline $11 \cdot 19 \cdot 92$ & CY1 & CY2 & CY3 & CY4 & CY5 & $\begin{array}{l}\text { Backup } \\
\text { Filter }\end{array}$ \\
\hline $\mathrm{D}_{\delta 0}, \mu \mathrm{m}$ & 8.35 & 5.14 & 2.72 & 1.89 & 0.79 & $\cdots$ \\
\hline $\begin{array}{l}\text { Mass } \\
\text { Collected, g }\end{array}$ & 5.2629 & 0.1398 & 0.0464 & 0.0182 & 0.0071 & 0.0156 \\
\hline$\%$ Total Mass & 95.86 & 2.55 & 0.85 & 0.33 & 0.13 & 0.28 \\
\hline $\begin{array}{l}\text { Mass Less } \\
\text { Than } D_{50} \text {, } \\
\text { cumulative \% }\end{array}$ & 4.14 & 1.59 & 0.75 & 0.41 & 0.28 & $\cdots$ \\
\hline \multicolumn{7}{|c|}{ Total Mass Collected $=5.4901 \mathrm{~g}$, Dust Loading $=2.691 \mathrm{gr} / \mathrm{scf}, \%$ Isokinetic $=100.0$} \\
\hline $04-27-93$ & CY1 & CY2 & CY3 & CY4 & CY5 & $\begin{array}{c}\text { Backup } \\
\text { Filter }\end{array}$ \\
\hline $\mathrm{D}_{50}, \mu \mathrm{m}$ & 8.50 & 5.17 & 2.73 & 1.91 & 0.80 & $\cdots$ \\
\hline $\begin{array}{l}\text { Mass } \\
\text { Collected, g }\end{array}$ & 2.5941 & 0.2837 & 0.2670 & 0.1340 & 0.0817 & 0.0262 \\
\hline$\%$ Total Mass & 76.60 & 8.38 & 7.88 & 3.96 & 2.41 & 0.77 \\
\hline $\begin{array}{l}\text { Mass Less } \\
\text { Than } \mathrm{D}_{50} \\
\text { cumulative \% }\end{array}$ & 23.40 & 15.03 & 7.14 & 3.19 & 0.77 & $\cdots$ \\
\hline \multicolumn{7}{|c|}{ Total Mass Collected $=3.3867 \mathrm{~g}$, Dust Loading $=1.6709 \mathrm{gr} / \mathrm{scf}, \%$ Isokinetic $=102.9$} \\
\hline $05 \cdot 14.93$ & CY1 & CY2 & CY3 & $\mathrm{CY} 4$ & CY5 & $\begin{array}{c}\text { Backup } \\
\text { Filter } \\
\end{array}$ \\
\hline $\mathrm{D}_{50}, \mu \mathrm{m}$ & 7.38 & 4.21 & 2.20 & 1.55 & 0.64 & $\cdots$ \\
\hline $\begin{array}{l}\text { Mass } \\
\text { Collected, g }\end{array}$ & 4.4662 & 0.7465 & 0.1675 & 0.0423 & 0.0236 & 0.0225 \\
\hline$\%$ Total Mass & 81.67 & 13.65 & 3.06 & 0.77 & 0.43 & 0.41 \\
\hline $\begin{array}{l}\text { Mass Less } \\
\text { Than } \mathrm{D}_{50} \text {, } \\
\text { cumulative \% }\end{array}$ & 18.33 & 4.68 & 1.62 & 0.84 & 0.41 & $\cdots$ \\
\hline
\end{tabular}

continued ... 
TABLE 6 (continued)

Steam Plant Multicyclone Data

\begin{tabular}{|c|c|c|c|c|c|c|}
\hline $08-04-93$ & CY1 & CY2 & CY3 & CY4 & CY5 & $\begin{array}{c}\text { Backup } \\
\text { Filter }\end{array}$ \\
\hline $\mathrm{D}_{\text {Б0 }}, \mu \mathrm{m}$ & 6.77 & 3.85 & 2.00 & 1.40 & 0.56 & $\cdots$ \\
\hline $\begin{array}{l}\text { Mass } \\
\text { Collected, g }\end{array}$ & 4.0157 & 1.7763 & 0.2531 & 0.1626 & 0.0536 & 0.0131 \\
\hline$\%$ Total Mass & 64.00 & 28.31 & 4.03 & 2.59 & 0.85 & 0.21 \\
\hline $\begin{array}{l}\text { Mass Less } \\
\text { Than } D_{50}, \\
\text { cumulative \% }\end{array}$ & 36.00 & 7.69 & 3.65 & 1.06 & 0.21 & $\cdots$ \\
\hline \multicolumn{7}{|c|}{ Total Mass Collected $=6.2744 \mathrm{~g}$, Dust Loading $=2.2821 \mathrm{gr} / \mathrm{scf}, \%$ Isokinetic $=103.2$} \\
\hline 09-10-93 & CY1 & CY2 & CY3 & CY4 & CY5 & $\begin{array}{c}\text { Backup } \\
\text { Filter }\end{array}$ \\
\hline $\mathrm{D}_{50}, \mu \mathrm{m}$ & 9.51 & 6.32 & 3.42 & 2.32 & 0.96 & $\cdots$ \\
\hline $\begin{array}{l}\text { Mass } \\
\text { Collected, g }\end{array}$ & 2.6665 & 0.1977 & 0.0847 & 0.0426 & 0.0503 & 0.0182 \\
\hline$\%$ Total Mass & 87.14 & 6.46 & 2.77 & 1.39 & 1.64 & 0.60 \\
\hline $\begin{array}{l}\text { Mass Less } \\
\text { Than } D_{50}, \\
\text { cumulative \% }\end{array}$ & 12.86 & 6.40 & 3.63 & 2.24 & 0.60 & $\cdots$ \\
\hline \multicolumn{7}{|c|}{ Total Mass Collected $=3.0600 \mathrm{~g}$, Dust Loading $=1.7974 \mathrm{gr} / \mathrm{scf}, \%$ Isokinetic $=100.6$} \\
\hline $09-29.93$ & CY1 & CY2 & CY3 & $\mathrm{CY} 4$ & CY5 & $\begin{array}{c}\text { Backup } \\
\text { Filter }\end{array}$ \\
\hline $\mathrm{D}_{60}, \mu \mathrm{m}$ & 9.22 & 6.05 & 3.26 & 2.22 & 0.92 & $\cdots$ \\
\hline $\begin{array}{l}\text { Mass } \\
\text { Collected, g }\end{array}$ & 3.5055 & 0.2566 & 0.1211 & 0.575 & 0.0583 & 0.0222 \\
\hline$\%$ Total Mass & 87.18 & 6.38 & 3.01 & 1.43 & 1.45 & 0.55 \\
\hline $\begin{array}{l}\text { Mass Less } \\
\text { Than } \mathrm{D}_{50} \text {, } \\
\text { cumulative \% }\end{array}$ & 12.82 & 6.44 & 3.43 & 2.00 & 0.55 & $\cdots$ \\
\hline
\end{tabular}


TABLE 6 (continued)

Steam Plant Multicyclone Data

\begin{tabular}{|c|c|c|c|c|c|c|}
\hline $10-28-93$ & CY1 & CY2 & CY3 & CY4 & CY5 & $\begin{array}{l}\text { Backup } \\
\text { Filter }\end{array}$ \\
\hline $\mathrm{D}_{50}, \mu \mathrm{m}$ & 10.90 & 7.87 & 4.38 & 2.90 & 1.19 & $\cdots$ \\
\hline $\begin{array}{l}\text { Mass } \\
\text { Collected, g }\end{array}$ & 2.6305 & 0.4687 & 0.2252 & 0.0716 & 0.0683 & 0.0331 \\
\hline$\%$ Total Mass & 75.21 & 13.40 & 6.44 & 2.05 & 1.95 & 0.95 \\
\hline $\begin{array}{l}\text { Mass Less } \\
\text { Than } \mathrm{D}_{50} \text {, } \\
\text { cumulative \% }\end{array}$ & 24.79 & 11.39 & 4.95 & 2.90 & 0.95 & $\ldots$ \\
\hline \multicolumn{7}{|c|}{ Total Mass Collected $=3.4974 \mathrm{~g}$, Dust Loading $=2.5283 \mathrm{gr} / \mathrm{scf}, \%$ Isokinetic $=99.90$} \\
\hline 11-23-93 & CY1 & CY2 & CY3 & CY4 & CY5 & $\begin{array}{c}\text { Backup } \\
\text { Filter }\end{array}$ \\
\hline $\mathrm{D}_{50}, \mu \mathrm{m}$ & 10.09 & 6.97 & 3.81 & 2.56 & 1.06 & $\ldots$ \\
\hline $\begin{array}{l}\text { Mass } \\
\text { Collected, g }\end{array}$ & 4.7901 & 0.9204 & 0.3537 & 0.1494 & 0.1008 & 0.0305 \\
\hline$\%$ Total Mass & 75.50 & 14.51 & 5.57 & 2.35 & 1.59 & 0.48 \\
\hline $\begin{array}{l}\text { Mass Less } \\
\text { Than } \mathrm{D}_{50}, \\
\text { cumulative \% }\end{array}$ & 24.50 & 10.00 & 4.42 & 2.07 & 0.48 & $\ldots$ \\
\hline
\end{tabular}

\subsection{KEY PERSONNEL STAFFING REPORT}

Table 7 presents planned versus actual work hours for key EERC personnel involved in the CFF project through December 1993. Work hours reported for Mr. Robie of RE\&C represent hours invoiced through October 1993.

TABLE 7

Planned Versus Actual Work Hours

for Key Project Personnel Through December 1993

\begin{tabular}{lccc}
\hline Key Personnel & Planned Hours & Actual Hours & \multicolumn{2}{c}{$\begin{array}{c}\text { Percentage of Total } \\
\text { Available Work Hours Used }\end{array}$} \\
\hline Greg F. Weber & 2290 & 2196 & 96 \\
Dennis L. Laudal & 3880 & 1110 & 29 \\
Chris Robie & 364 & 41 & 11 \\
\hline
\end{tabular}




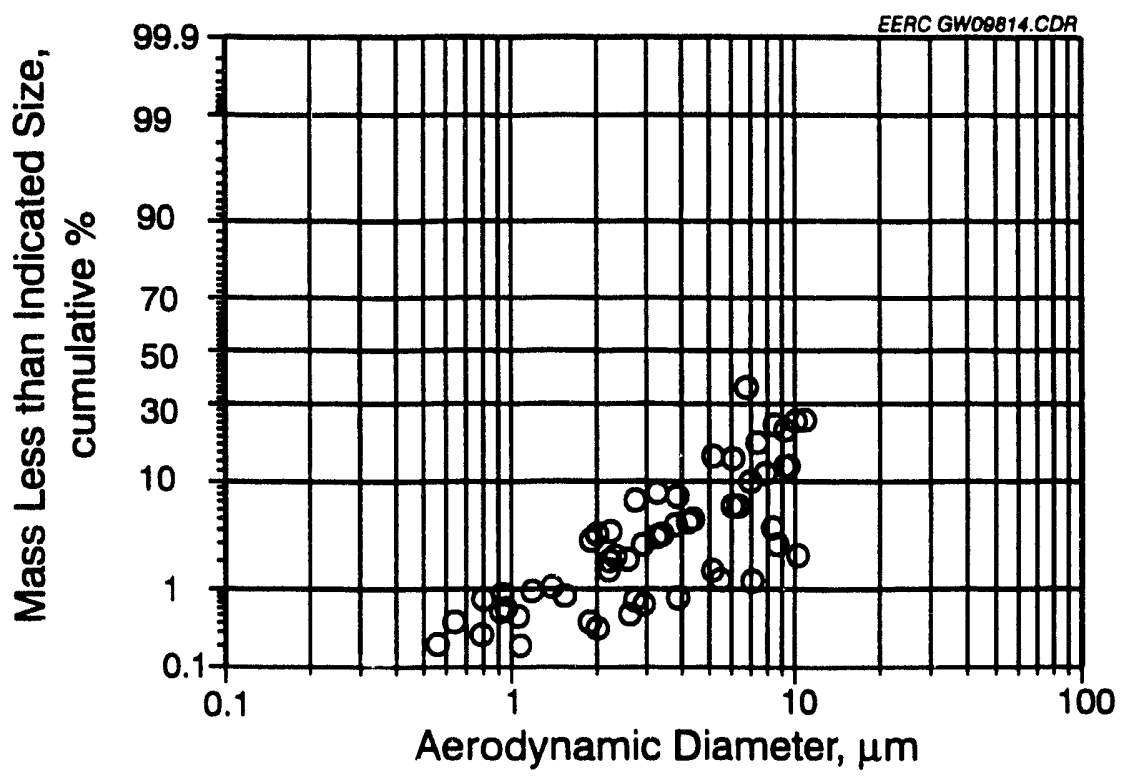

Figure 7. A summary of multicyclone data for ash collected in the steam piant baghouse.

\subsection{REFERENCES}

1. Pirsh, E.A. U.S. Patent 4220 633, Sept. 2, 1980, assigned to Babcock \& Wilcox Co.

2. Pirsh, E.A. U.S. Patent 4309 386, Jan. 5, 1982, assigned to Babcock \& Wilcox Co.

3. Doyle, J.B. et al. U.S. Patent 4793 981, Dec. 27, 1988, assigned to Babcock \& Wilcox Co.

4. Weber, G.F. "SO$\times \mathrm{NO}_{\mathrm{x}}$ Control, Low-Rank Coal Research Under the UND/DOE Cooperative Agreement," quarterly technical progress report DOE/FE/60181-1531; EERC publication, Jan. 1984; Section 6.

5. Kalinowski, M.R.; Nishioka, G.M. "Method for Applying Porous Metal Oxide Coatings to Relatively Nonporous Fibrous Substrates," U.S. Patent 4732 879, March 22, 1988.

6. Weber, G.F.; Laudal, D.L. "SO $/ \mathrm{NO}_{\mathrm{x}}$ Control - CFF for Simultaneous $\mathrm{NO}_{\mathrm{x}}$ and Particulate Control," final technical report for the period April 1, 1988, through June 30, 1989; DE-FC21-86MC10637, EERC publication, Aug. 1989.

7. Weber, G.F.; Miller, S.J.; Laudal, D.L. "Flue Gas Cleanup," final technical report for the period July 1, 1989, through June 30, 1990; DE-FC21-86MC10637, EERC publication, Oct. 1990. 
EERC GWOBB 10.CDR

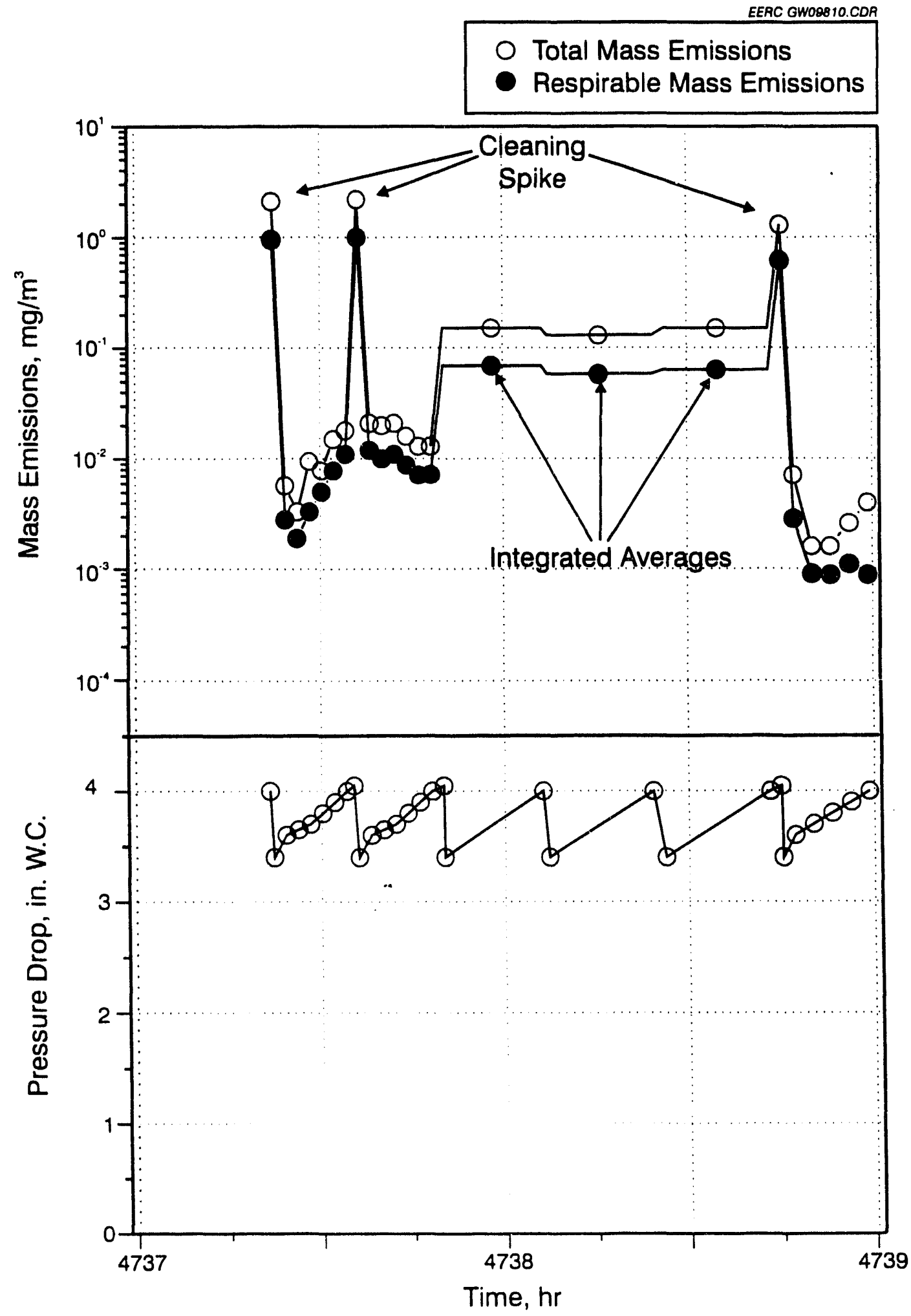

Figure 8. Mass emissions and pressure drop as a function of time for the steam plant baghouse, November 23, 1993. 
8. Chen, J.P.; Buzanowski, M.A.; Yang, R.T.; Cichanowicz, J.E. "Deactivation of the Vanadia Catalyst in the Selective Catalytic Reduction Process," J. Air Waste Manage. Assoc. 1990, 40, 1403-1409.

9. Weber, G.F.; Ness, S.R.; Laudal, D.L.; Dunham, G.E. "CFF For Simultaneous NO and Particulate Control," EERC publication, August 1993. 


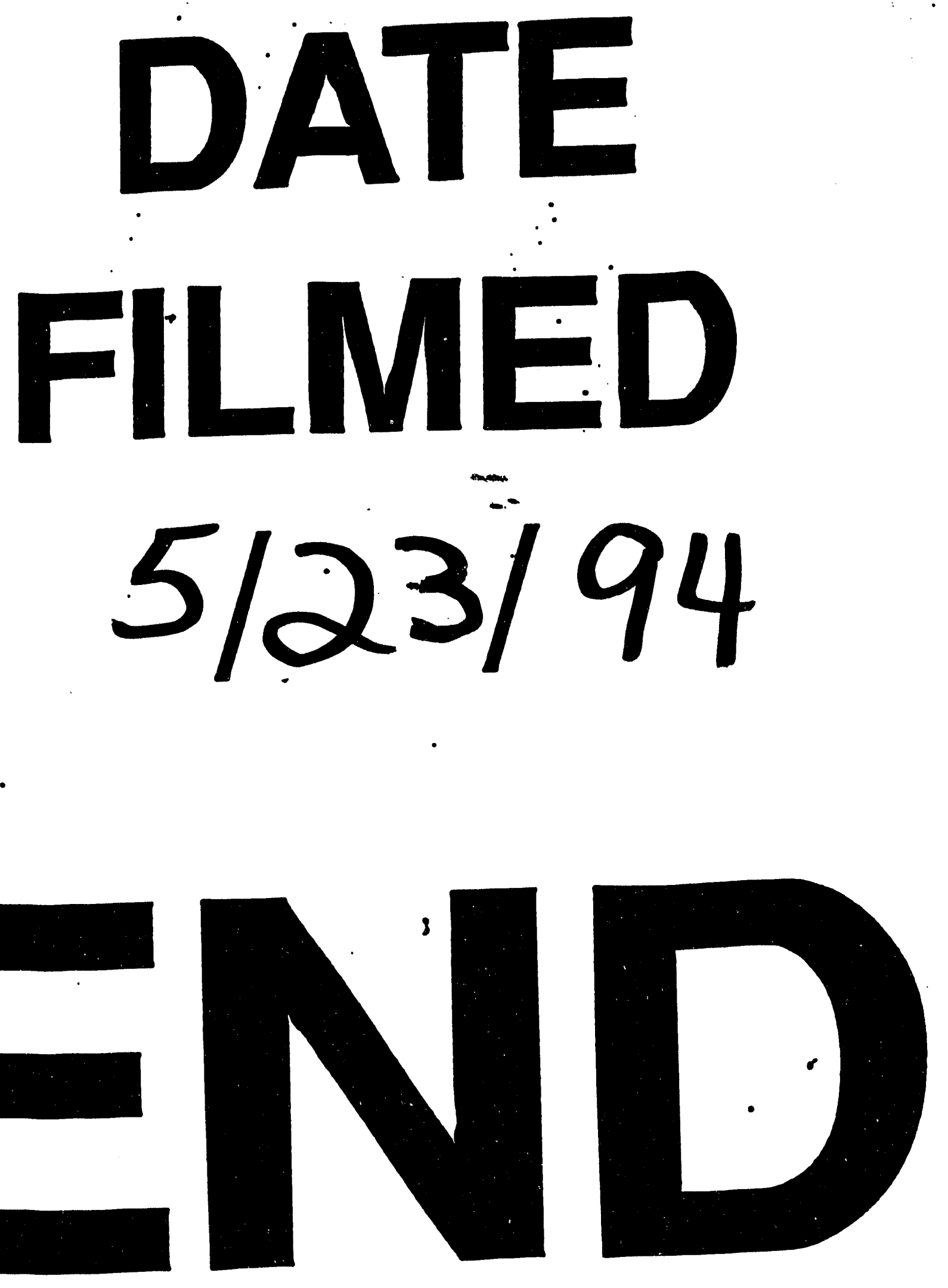


